\title{
The Importance of an Inter-compartmental Delay in a Model for Human Gastric Acid Secretion
}

\author{
SIMEONE MARINO*, SUMAN GANGULI*, IAN M. P. JOSEPH AND \\ DENISE E. KIRSCHNER ${ }^{\dagger}$ \\ Department of Microbiology and Immunology, \\ University of Michigan Medical School, \\ Ann Arbor, Michigan, \\ USA \\ E-mail: simeonem@umich.edu
}

In this work we re-examine an existing model of gastric acid secretion. The model is a 2-compartment model of the human stomach accounting for regions where relevant cells (D, G, ECL and parietal cells) and proteins and acid they secrete (somatostatin, gastrin, histamine, and gastric acid, respectively) are found. These proteins compose a positive and negative feedback system that controls the secretion of gastric acid by parietal cells. The original model consists of 18 ordinary differential equations and yields a stable 3-period limit cycle solution. We modify the existing model by introducing a delay into the system and assuming that the cell populations are in steady state over a short-time window $(<300 \mathrm{~h})$ and are able to reduce the system to an 8-equation delay differential equation model. In addition to demonstrating congruency between the two models, we also show that a similar stability is only reproducible when the delay in gastrin transport is approximately $30 \mathrm{~min}$. This suggests that gastric acid secretion homeostasis likely depends strongly on the delay in gastrin transport from the antrum to the corpus.

(c) 2003 Society for Mathematical Biology. Published by Elsevier Ltd. All rights reserved.

\section{INTRODUCTION}

Secretion of gastric acid from parietal cells into the lumen of the stomach is a highly regulated and dynamic process dependent on neural, paracrine and endocrine control. Adding to its complexity is the presence of many redundant mechanisms that ensure proper function of the cellular and physiological mechanisms involved in regulation of acid secretion. Numerous experimental studies have characterized positive and negative regulatory mechanisms involved in acid

\footnotetext{
*Equal contribution.

†Corresponding address: Department of Microbiology and Immunology, University of Michigan Medical School, 6730 Medical Science Building II, Ann Arbor, Michigan 48109-0620, USA.

E-mail:kirschne@umich.edu
} 
secretion; however, much remains unknown about this process, such as the precise role played by certain hormones in gastric physiology.

The use of mathematical models to study physiological processes has provided significant insight that was not possible through experimental study. Several mathematical models describing acid secretion have previously been published (Engel et al., 1984; Licko and Ekblad, 1992a,b; de Beus et al., 1993; Keener and Sneyd, 1998). The model presented by de Beus et al. (1993) provided insight into the coupling of gastric acid to bicarbonate secretion and in particular analyzed the cascade of molecular and ionic events necessary for the acid secretion. Likewise, Licko and Ekblad (1992a) present an extensive analysis of gastric acid secretion. They addressed the mechanics of acid secretion as a sequential two-step process involving the formation of acid that contributes to a storage pool and the subsequent translocation of the stored acid. Although both models are detailed and insightful, they do not address the regulatory processes involved in the modulation of acid secretion.

Joseph et al. (2002) developed the first mathematical model to extensively address regulation of gastric acid. Four cell populations, i.e., G, D, ECL and parietal cells, are essential for acid secretion, while the effectors they secrete (hormones, cellular factors and neural stimuli) primarily regulate acid secretion. This model indicated that gastrin played a key role in governing the dynamics of this regulated feedback system. For example, varying the transport rate of gastrin between the antral and corpus regions significantly impacts secreted acid. Furthermore, during periods of acid suppression, gastrin was also observed to play an important role in restoring acid homeostasis.

In this paper, we attempt to improve the existing nonlinear system of ordinary differential equations (ODEs) (Joseph et al., 2002) through the implementation of a novel DDE formulation yielding a significant reduction in the number of equations and parameters in the DDE setting.

We outline key elements of stomach physiology in the next section, leading to a detailed description of the existing ODE model from Joseph et al. (2002). We highlight the relevant changes that have been made to convert the ODE system to a DDE system. Next, we describe the DDE formulation and the form of the delay functions is discussed and implemented. Finally, we compare baseline behavior of both models, as well as their consistency by means of virtual deletion/depletion experiments. We also perform a qualitative study of their behavior by means of phase plot analysis.

\section{The Stomach Physiology}

The stomach is divided into several histological regions, but for the purpose of these models they have been condensed into two functional regions (see Fig. 1): the corpus (upper) and the antrum (lower). Food enters into the corpus first, then flows into the antrum. 


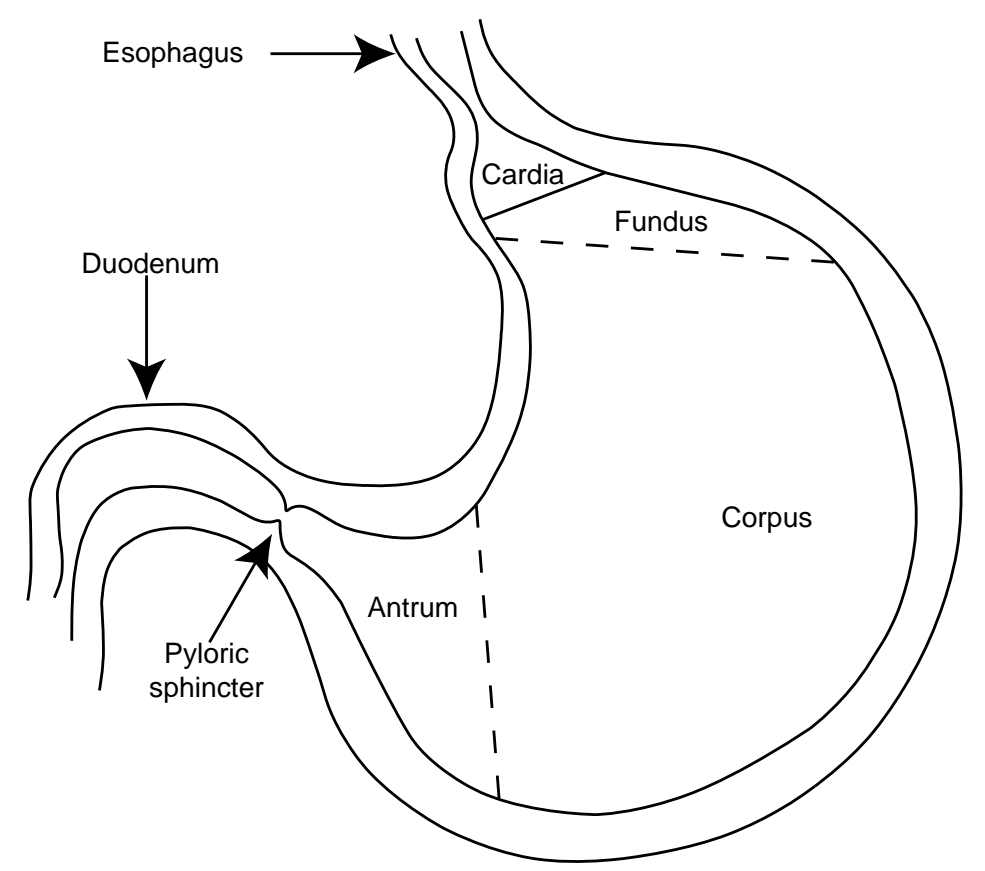

Figure 1. Section of the stomach anatomy. A general layout of the stomach is illustrated, from the esophagus to the pyloric sphincter, including the corpus and the antrum regions.

A two-compartmental ODE model was developed: it describes the known biological processes occurring within the corpus and antrum during acid secretion (Joseph et al., 2002). The key elements included in the model are cells, hormones, cellular factors, neural stimuli, acid and gastric protective mechanisms. Implicit in the model is that the two major regions of the stomach perform different tasks; the antrum transduces chemical and physical information into the lumen through modulation of gastrin levels, ultimately regulating the appropriate responses in the corpus (Hersey and Sachs, 1995). An outline of the elements in the model follows; for further details see Joseph et al. (2002).

Cell populations. The cells included in the model are: somatostatin-secreting delta (D) cells, gastrin-secreting (G) cells, histamine-secreting enterochromaffinlike (ECL) cells, and parietal cells. These cells secrete somatostatin, gastrin, histamine, and hydrochloric acid $(\mathrm{HCl})$, respectively. Stem cells were also included to provide a more physiologically complete context.

Seven cell populations were monitored in the ODE model: stem cells in the antrum and corpus; $\mathrm{G}$ cells in the antrum; D cells in the antrum and corpus; and ECL and parietal cells in the corpus. The dynamics of endocrine and exocrine cell populations (G, D, ECL and parietal cells) within the antrum and corpus share similar differentiation pathways and feedback mechanisms (Joseph et al., 2002). 
Neural components, bicarbonate and feeding function. The ODE model also includes central nervous system (CNS) and enteric nervous system (ENS) stimuli with the CNS directly stimulating acid release from parietal cells (Debas and Carvajal, 1994) and gastrin release from G cells (Matsuno et al., 1997). Bicarbonate ions (B) are included for gastric protection and to correctly scale acid levels.

As in Joseph et al. (2002), we model food intake with a feeding function that includes three meals a day and is proportional to food volume $(\mathrm{Fd}(t))$ consumed at each meal. We model a standard American diet in which the amount of food consumed increases with each meal during the day (times $0700 \mathrm{~h}, 1300 \mathrm{~h}$, and $1900 \mathrm{~h}$ ). Food volume ranges between 0.0 and 1.01 , with 1.51 as the maximal volume of the stomach (see Appendix for equation and graph of the feeding function). The underlying principle is that food ingestion increases the volume of the luminal contents, promoting distension of the stomach (Hersey and Sachs, 1995). The stretching of the stomach walls stimulates mechanoreceptors, resulting in gastrin release (Konturek et al., 1982; Weigert et al., 1997).

Effector regulation of acid secretion. G, D and ECL cells secrete effectors upon receiving appropriate stimuli. G cells in the antrum secrete gastrin, a positive regulator of gastric acid secretion, upon receipt of ENS and CNS stimuli (Blair et al., 1986; Lundell et al., 1987; Campos et al., 1990; Dockray, 1999). Secreted gastrin diffuses into the antral blood capillaries. Gastrin is transported from the antrum to the corpus where it diffuses into the extracellular space. A delay effectively results from the time gastrin is secreted in the antrum and the observance of its effects in the corpus. This delay is likely on the order of $30 \mathrm{~min}$ (Chew and Hersey, 1982) and may be critical for acid homeostasis.

The primary inhibitory effector of acid secretion is somatostatin, secreted by $\mathrm{D}$ cells in both the antrum and corpus. The CNS plays an important role in inhibiting release of somatostatin and promoting the release of positive effectors of gastric acid (Nishi et al., 1985). However, as the concentration of gastrin increases, gastrin stimulates D cells to secrete somatostatin into the corpus of the stomach (Saffouri et al., 1980; Koop et al., 1982). In the corpus, gastrin induces secretion of histamine from ECL cells (Hakanson et al., 1998; Lindstrom and Hakanson, 2001; Lindstrom et al., 2001). The proximity of ECL cells to parietal cells ensures that only diffusion of histamine is necessary for stimulation of acid secretion (Lindstrom et al., 2001). Histamine not only stimulates acid secretion, it also enables gastrin-stimulated acid release in a dose-dependent manner (Wollin, 1987).

\section{THE ODE MODEL}

In this section we illustrate the equations of the ODE model, as presented in Joseph et al. (2002). 
Cell populations dynamics. Stem cells in both the antrum and the corpus undergo differentiation to G, D, ECL and parietal cells (Karam, 1995; Karam and Leblond, 1995; Karam et al., 1997; Karam, 1999). $\gamma_{\text {Asc }}$ and $\gamma_{\text {Csc }}$ represent the antral and corpus stem cells rates of division.

Proliferation of stem cell populations has been modeled using logistic growth. This leads to the following differential equations for the rate of change of stem cell populations (units for the rates of change of cells are cells per hour in the total stomach):

Antral stem cells.

$\frac{d A_{s c}(t)}{d t}=\left(\gamma_{\mathrm{Asc}}\right)\left(A_{s c}(t)\right)\left(C_{\mathrm{Asc}}-A_{s c}(t)\right)-\left(p_{\mathrm{G}}(t)+p_{D_{A}}(t)\right)\left(\eta_{\mathrm{Asc}}\right)\left(A_{s c}(t)\right)$.

\section{Corpus stem cells.}

$$
\begin{aligned}
\frac{d C_{s c}(t)}{d t}= & \left(\gamma_{\mathrm{Csc}}\right)\left(C_{s c}(t)\right)\left(C_{\mathrm{Csc}}-C_{s c}(t)\right)+\left(\frac{g_{\mathrm{max}} \cdot\left[G t n_{C}(t)\right]^{2}}{\left[G t n_{C}(t)\right]^{2}+\alpha_{\mathrm{Csc}}^{2}}\right) \cdot C_{s c}(t) \\
& -\left(p_{E}(t)+p_{D_{C}}(t)+p_{P}(t)\right)\left(\eta_{\mathrm{Csc}}\right)\left(C_{s c}(t)\right)
\end{aligned}
$$

The additional term $\left(\frac{g_{\max } \cdot\left[\operatorname{Gtn}_{C}(t)\right]^{2}}{\left[G n_{C}(t)\right]^{2}+\alpha_{\mathrm{Csc}}^{2}}\right)$ in (1.2) accounts for the gastrin-induced growth of corpus stem cells. In equations (1.1) and (1.2), the functions $p_{G}, p_{D_{A}}$, $p_{E}, p_{D_{C}}$ and $p_{P}$ represent the feedback mechanisms by which the level of each type of cell modulates stem cell differentiation (Sato et al., 1972).

The equations for the rate of change of endocrine cells (i.e., G, D and ECL) and the exocrine (parietal) cells dynamics are as follows (Joseph et al., 2002):

G cells.

$$
\begin{aligned}
\frac{d G(t)}{d t}= & p_{G}(t) \cdot \eta_{\mathrm{Asc}} \cdot A_{s c}(t)+k_{g \max } \cdot\left(1-\frac{\left[A_{A}(t)\right]^{2}}{\left[A_{A}(t)\right]^{2}+\alpha_{H_{A}}^{2}}\right) \cdot G(t) \\
& -\lambda_{f d \max } \cdot\left(1-\frac{(F d(t))^{2}}{(F d(t))^{2}+\alpha_{f d}^{2}}\right) \cdot G(t)-\lambda_{G_{c}} \cdot G(t) .
\end{aligned}
$$

Corpus D cells.

$$
\frac{d D_{C}(t)}{d t}=p_{D_{C}}(t) \cdot \eta_{\mathrm{Asc}} \cdot C_{s c}(t)-\lambda_{D_{C}} \cdot D_{C}(t)
$$


Antral D cells.

$$
\begin{aligned}
\frac{d D_{A}(t)}{d t}= & p_{D_{A}}(t) \cdot \eta_{\mathrm{Asc}} \cdot A_{s c}(t)+\left(\frac{k_{d \max }\left[A_{A}(t)\right]^{2}}{\left[A_{A}(t)\right]^{2}+\alpha_{H_{A}}^{2}}\right) \cdot D_{A}(t) \\
& -\lambda_{D_{A}} \cdot D_{A}(t)+\lambda_{f d \max } \cdot\left(1-\frac{(F d(t))^{2}}{(F d(t))^{2}+\alpha_{f d}^{2}}\right) \cdot G(t) .
\end{aligned}
$$

ECL cells.

$$
\frac{d E(t)}{d t}=p_{E}(t) \cdot \eta_{\mathrm{Csc}} \cdot C_{s c}(t)-\lambda_{E} \cdot E(t)+\left(\frac{k_{e \max } \cdot\left[G t n_{c}(t)\right]^{2}}{\left[G t n_{c}(t)\right]^{2}+\alpha_{E}^{2}}\right) \cdot E(t) .
$$

Parietal cells.

$$
\frac{d P(t)}{d t}=p_{P}(t) \cdot \eta_{\mathrm{Csc}} \cdot C_{s c}(t)-\lambda_{P} \cdot P(t)
$$

Endocrine and parietal cells undergo death at rate $\lambda$ specific to the cell type (Pansu et al., 1977; Inokuchi et al., 1983; Hattori and Arizono, 1988). As data on lifespans of human cells is scarce, we estimated these rates from published studies conducted in mice (Karam, 1993; Karam and Leblond, 1993a,b,c,d). The term $\lambda_{f d \max } \cdot\left(1-\frac{(F d(t))^{2}}{(F d(t))^{2}+\alpha_{f d}^{2}}\right)$ in (1.5) takes into account the fact that as food intake $(F d(t))$ is reduced the rate of loss of $G$ cells increases towards $\lambda_{f d \max }$ (Schwarting et al., 1986). In contrast, high acid levels $\left(A_{c}(t)\right)$ may limit the growth of $G$ cells in the corpus, while promoting growth of antral $D$ cells (Arnold et al., 1986). These two effects have been included in the model by $k_{g \text { max }} \cdot\left(1-\frac{\left[A_{c}(t)\right]^{2}}{\left[A_{c}(t)\right]^{2}+\alpha_{H_{A}}^{2}}\right)$ in (1.3) and $\left(\frac{k_{d} \max \left[A_{A}(t)\right]^{2}}{\left[A_{A}(t)\right]^{2}+\alpha_{H_{A}}^{2}}\right)$ in (1.5). Gastrin-mediated proliferation of ECL cells (Dockray, 1999; Chen et al., 1999a; Koh and Chen, 2000) has been modeled in (1.6) with the Michaelis-Menten term $\left(\frac{k_{e \max } \cdot\left[G t n_{c}(t)\right]^{2}}{\left[G t n_{c}(t)\right]^{2}+\alpha_{E}^{2}}\right)$.

Hormonal regulation of acid secretion. Equations for the kinetics of antral and corpus gastrin $\left(G t n_{A}(t)\right.$ and $\left.G t n_{c}(t)\right)$, antral and corpus somatostatin $\left[S_{A}(t)\right.$ and $S_{c}(t)$ ] and histamine $\left(H_{c}(t)\right)$ are as follows [units for the rates of change for hormones and bicarbonate are M (mole) per hour] (Joseph et al., 2002):

Antral gastrin.

$$
\frac{d\left[G t n_{A}(t)\right]}{d t}=G(t)\left(\frac{K_{N G_{1}}\left[N_{E}(t)\right]}{\left(\left[N_{E}(t)\right]+\alpha_{N G 1}\right)\left(1+\frac{\left[S_{A}(t)\right]}{k_{S G}}\right)\left(1+\frac{\left[A_{c}(t)\right]^{2}}{\left[A_{c}(t)\right]^{2}+k_{A G}^{2}}\right)}\right)
$$




$$
\begin{aligned}
& +G(t)\left(\frac{k_{N G_{2}}\left[N_{C}(t)\right]}{\left(\left[N_{C}(t)\right]+\alpha_{N G 2}\right)\left(1+\frac{\left[S_{A}(t)\right]}{k_{S_{G}}}\right)\left(1+\frac{\left[A_{c}(t)\right]^{2}}{\left[A_{c}(t)\right]^{2}+k_{A G}^{2}}\right)}\right) \\
& +G(t)\left(\frac{K_{F G}[F d(t)]}{\left([F d(t)]+\alpha_{F D}\right)\left(1+\frac{\left[S_{A}(t)\right]}{k_{S G}}\right)\left(1+\frac{\left[A_{c}(t)\right]^{2}}{\left[A_{c}(t)\right]^{2}+k_{A G}^{2}}\right)}\right) \\
& -\left(k_{G}+\beta_{G}\right)\left[G t n_{A}(t)\right] .
\end{aligned}
$$

Corpus gastrin.

$$
\frac{d\left[G t n_{C}(t)\right]}{d t}=\beta_{G}\left[G t n_{A}(t)\right]-\kappa_{G}\left[G t n_{C}(t)\right]
$$

Antral somatostatin.

$$
\begin{aligned}
& \frac{d\left[S_{A}(t)\right]}{d t}=D_{A}(t)\left(\frac{K_{A S}\left[A_{A}(t)\right]}{\left(\left[A_{A}(t)\right]+\alpha_{A S}\right)\left(1+\frac{\left[S_{A}(t)\right]}{k_{S S}}\right)\left(1+\frac{\left[N_{C}(t)\right]}{k_{N S}}\right)}\right) \\
& \quad+D_{A}(t)\left(\frac{K_{N S 1}\left[N_{E}(t)\right]}{\left(\left[N_{E}(t)\right]+\alpha_{N S 1}\right)\left(1+\frac{\left[S_{A}(t)\right]}{k_{S S}}\right)\left(1+\frac{\left[N_{C}(t)\right]}{k_{N S}}\right)}\right) \\
& -\kappa_{S}\left[S_{A}(t)\right] .
\end{aligned}
$$

\section{Corpus somatostatin.}

$$
\begin{aligned}
& \frac{d\left[S_{C}(t)\right]}{d t}=D_{C}(t)\left(\left(\frac{K_{N S 2}\left[N_{E}(t)\right]}{\left(\left[N_{E}(t)\right]+\alpha_{N S 2}\right)\left(1+\frac{\left[S_{C}(t)\right]}{k_{S S}}\right)\left(1+\frac{\left[N_{C}(t)\right]}{k_{N S}}\right)}\right)\right) \\
& \quad+D_{C}(t)\left(\frac{K_{G S}\left[G t n_{C}(t)\right]}{\left(\left[G t n_{C}(t)\right]+\alpha_{G S}\right)\left(1+\frac{\left[S_{C}(t)\right]}{k_{S S}}\right)\left(1+\frac{\left[N_{C}(t)\right]}{k_{N S}}\right)}\right) \\
& -\kappa_{S}\left[S_{C}(t)\right] .
\end{aligned}
$$

Histamine.

$$
\frac{d\left[H_{C}(t)\right]}{d t}=E(t)\left(\left(\frac{K_{N H}\left[N_{E}(t)\right]}{\left(\left[N_{E}(t)\right]+\alpha_{N H}\right)\left(1+\frac{\left[S_{C}(t)\right]}{k_{S H}}\right)}\right)\right)
$$




$$
\begin{aligned}
& +E(t)\left(\frac{K_{G H}\left[G t n_{C}(t)\right]}{\left(\left[G t n_{C}(t)\right]+\alpha_{G H}\right)\left(1+\frac{\left[S_{C}(t)\right]}{k_{S H}}\right)}\right) \\
& -\kappa_{H}\left[H_{C}(t)\right] .
\end{aligned}
$$

Antral gastrin, namely equation (1.8), is secreted by $G$ cells in response to neural [both from CNS, $N_{C}(t)$ and ENS, $N_{E}(t)$ ] and mechanical stimuli [i.e., food$F d(t)$ ]. Experimental evidence suggests that somatostatin, the primary inhibitor of gastric acid secretion $\left(A_{C}(t)\right)$, acts in a noncompetitive manner (Chew, 1983). Therefore, an inhibitory term of the general form $\left(1+\frac{[I(t)]}{k}\right)$ has been included where needed. If two inhibitors exist, as in the case of inhibition of somatostatin secretion by both somatostatin and the CNS, equations (1.10) and (1.11), we use the product of the inhibitory terms $\left(1+\frac{\left[S_{C}(t)\right]}{k_{S M}}\right)\left(1+\frac{\left[N_{c}(t)\right]}{k_{N S}}\right)$ to capture the inhibitory dynamics. The loss of gastrin from the antrum occurs via two mechanisms: transport and degradation. We model these with the loss term $-\left(k_{G}+\beta_{G}\right)\left[G t n_{A}(t)\right]$, i.e., we assume that both losses are directly proportional to the gastrin concentration in the antrum at time $t$.

Similar to the hormone dynamics described earlier, stimuli affecting parietal cells affects acid secretion. The equations for the kinetics of antral and corpus acid $\left(A_{A}(t)\right.$ and $\left.A_{c}(t)\right)$ are as follows (Joseph et al., 2002):

Corpus acid.

$$
\begin{aligned}
\frac{d\left[A_{C}(t)\right]}{d t}= & P(t)\left(\left(\frac{K_{H A}\left[H_{C}(t)\right]}{\left(\left[H_{C}(t)\right]+\alpha_{H A}\right)\left(1+\frac{\left[S_{C}(t)\right]}{k_{S A}}\right)}\right)\right. \\
& \left.+\left(\frac{\left[H_{C}(t)\right]}{\left[H_{C}(t)\right]+\alpha_{H}}\right)\left(\frac{K_{G A}\left[G t n_{C}(t)\right]}{\left(\left[G n_{C}(t)\right]+\alpha_{G A}\right)\left(1+\frac{\left[S_{C}(t)\right]}{k_{S A}}\right)}\right)\right) \\
& +P(t)\left(\frac{K_{N A}\left[N_{C}(t)\right]}{\left(\left[N_{C}(t)\right]+\alpha_{N A}\right)\left(1+\frac{\left[S_{C}(t)\right]}{k_{S A}}\right)}\right)-h b\left[A_{C}\right]\left[B_{C}\right] \\
& -\left[A_{C}(t)\right] \frac{k_{f \max } F d(t)}{F d(t)+\alpha_{F A}}-\beta_{A}\left[A_{C}(t)\right] .
\end{aligned}
$$

Antral acid.

$$
\frac{d\left[A_{A}(t)\right]}{d t}=\beta_{A}\left[A_{c}(t)\right]-\kappa_{A}\left[A_{A}(t)\right] .
$$

Histamine, gastrin and CNS elicit the secretion of acid from parietal cells, while somatostatin acts noncompetitively to inhibit acid secretion [equation (1.13)]. Loss 
of gastric acid from the corpus region occurs at a rate $\beta_{A}$. This acid diffuses to the antral region where it reappears as the source term in the differential equation describing the rate of change of antral gastric acid [equation (1.14)]. Buffering of acid by bicarbonate $\left(B_{c}(t)\right)$ leads to further loss of acid [the mass-action term $\left[h b A_{c}(t)\right]\left[B_{c}(t)\right]$ in (1.13)]. Food consumed also buffers acid and this is represented in equation (1.13) by the term $\left[A_{C}(t)\right] \frac{k_{f \max } F d(t)}{F d(t)+\alpha_{F A}}$.

Bicarbonate. The differential equations for bicarbonate ion concentrations take into account that the behavior of bicarbonate secretion follows Michaelis-Menten kinetics. The differential equations that describe the change in bicarbonate concentration in the corpus and antrum are given by Joseph et al. (2002) (the units for the rate of change for bicarbonate are $\mathrm{M}$ per hour):

Corpal bicarbonate.

$$
\frac{d\left[B_{c}(t)\right]}{d t}=\frac{k_{b c \max }\left[N_{c}(t)\right]}{\left[N_{c}(t)\right]+\alpha_{N B}}-h b\left[A_{c}(t)\right]\left[B_{c}(t)\right]-\beta_{b}\left[B_{c}(t)\right] .
$$

\section{Antral bicarbonate.}

$$
\frac{d\left[B_{A}(t)\right]}{d t}=\frac{k_{b A \max }\left[N_{c}(t)\right]}{\left[N_{c}(t)\right]+\alpha_{N B}}-h b\left[A_{A}(t)\right]\left[B_{A}(t)\right]-\kappa_{b}\left[B_{A}(t)\right] .
$$

Loss of free bicarbonate from the system occurs via buffering of acid, transport to the antrum from the corpus and from washout from the antrum to the intestines. The rates of transport $\left(\beta_{b}\right)$ and washout $\left(\kappa_{b}\right)$ of bicarbonate should be equivalent to the respective rates of transport and washout of acid. How bicarbonate is able to effectively buffer secreted acid is not well understood. We assume that bicarbonate released by gastric epithelial cells forms a 'wavefront' that is basic. The basic wavefront serves to buffer acid diffusing back into the mucus layer from the lumen establishing a $\mathrm{pH}$ gradient. The overall effect is that the lumen of the stomach is acidic $(\mathrm{pH} 2)$ and the muco-epithelial cell interface is neutral $(\mathrm{pH} \sim 7)$.

Neural stimuli. The central and enteric neural stimuli, $\left[N_{C}(t]\right]$ and $\left[N_{E}(t)\right]$ respectively, are driven by food stimulus $(F d(t))$. The following differential equations define central and enteric neural activity, respectively:

Central nervous system-CNS.

$$
\frac{d\left[N_{c}(t)\right]}{d t}=\left(\frac{N_{\max 1} F d(t)}{\left(F d(t)+k 1_{f d}\right)\left(1+\frac{\left[A_{c}(t)\right]^{2}}{\left[A_{c}(t)\right]^{2}+k_{A N 1}^{2}}\right)}\right)-\kappa_{N_{C}}\left[N_{C}(t)\right]+\operatorname{Bas}_{1} .
$$


Enteric nervous system-ENS.

$$
\frac{d\left[N_{E}(t)\right]}{d t}=\left(\frac{N_{\max 2} F d(t)}{\left(F d(t)+k 2_{f d}\right)\left(1+\frac{\left[A_{c}(t)\right]^{2}}{\left[A_{c}(t)\right]^{2}+k_{A N 2}^{2}}\right)}\right)-\kappa_{N_{E}}\left[N_{E}(t)\right]+B a s_{2} .
$$

Feedback from the luminal acidic environment is accomplished through noncompetitively inhibiting neural activity, represented by $\left(1+\frac{\left[A_{c}(t)\right]^{2}}{\left[A_{c}(t)\right]^{2}+k_{A N 1}^{2}}\right)$. In addition, basal neural activity in the CNS and ENS has been considered in the form of $B a s_{1}$ and $\mathrm{Bas}_{2}$, respectively. The feeding function $[F d(t)]$ is illustrated in the Appendix.

\section{THE DDE MODEL}

The food function clearly drives stomach physiology and its dynamics, affecting both directly and indirectly cells and neural stimuli. The feeding function primarily induces $\mathrm{G}$ cells to secrete gastrin, determining the main feedback loop of the system (from corpus to antrum). This in turn results in $\mathrm{HCl}$ action on antral gastrin. Since there is a delay between the time gastrin is secreted in the antrum and the observation of its effects in the corpus, we implement a delay function to account for this. To this end, corpus gastrin is replaced by a delay function and hence equation (1.9) is no longer needed. The natural choice is to represent the delay effect as a function of the past levels of antral gastrin, i.e., $\int_{t-\tau}^{t} f\left(G t n_{A}(t)\right) d t$ for some $\tau$. Different forms for the delay function $f\left(\operatorname{Gtn}_{A}(t)\right)$ will be described at the end of this section.

We also hypothesize that histamine is always present in the corpus, allowing gastrin to exert its stimulatory effect on parietal cell acid secretion. We implicitly assume that the amount of histamine released by ECL cells is proportional to the amount of antral gastrin released in the previous $\tau$ min. Thus, the effect of histamine on parietal cells (upregulation of corpus $\mathrm{HCl}$ production) is also included in the delay term, and equation (1.12) for histamine can be eliminated. Since the main producers of histamine are the ECL cells [equation (1.6)], they too can be deleted from the model, and the original effect of the ENS on ECL cells has been neglected since it is considered secondary.

In gastric acid secretion, histamine released by ECL cells functions to amplify the effects of gastrin on parietal cells. However, its activity is not required for acid stimulation as histamine depletion and deletion experiments show only moderate changes in acid secretion (Dockray, 1999; Lindstrom and Hakanson, 2001). In these cases, it is likely that acid secretion is compensated for through CNS stimulation and some gastrin signaling. Although without histamine in the model the results of the DDE and ODE models are qualitatively similar, to ensure quantitative comparisons we augment the DDE model by increasing the sensitivity of parietal cells to gastrin stimulation. 


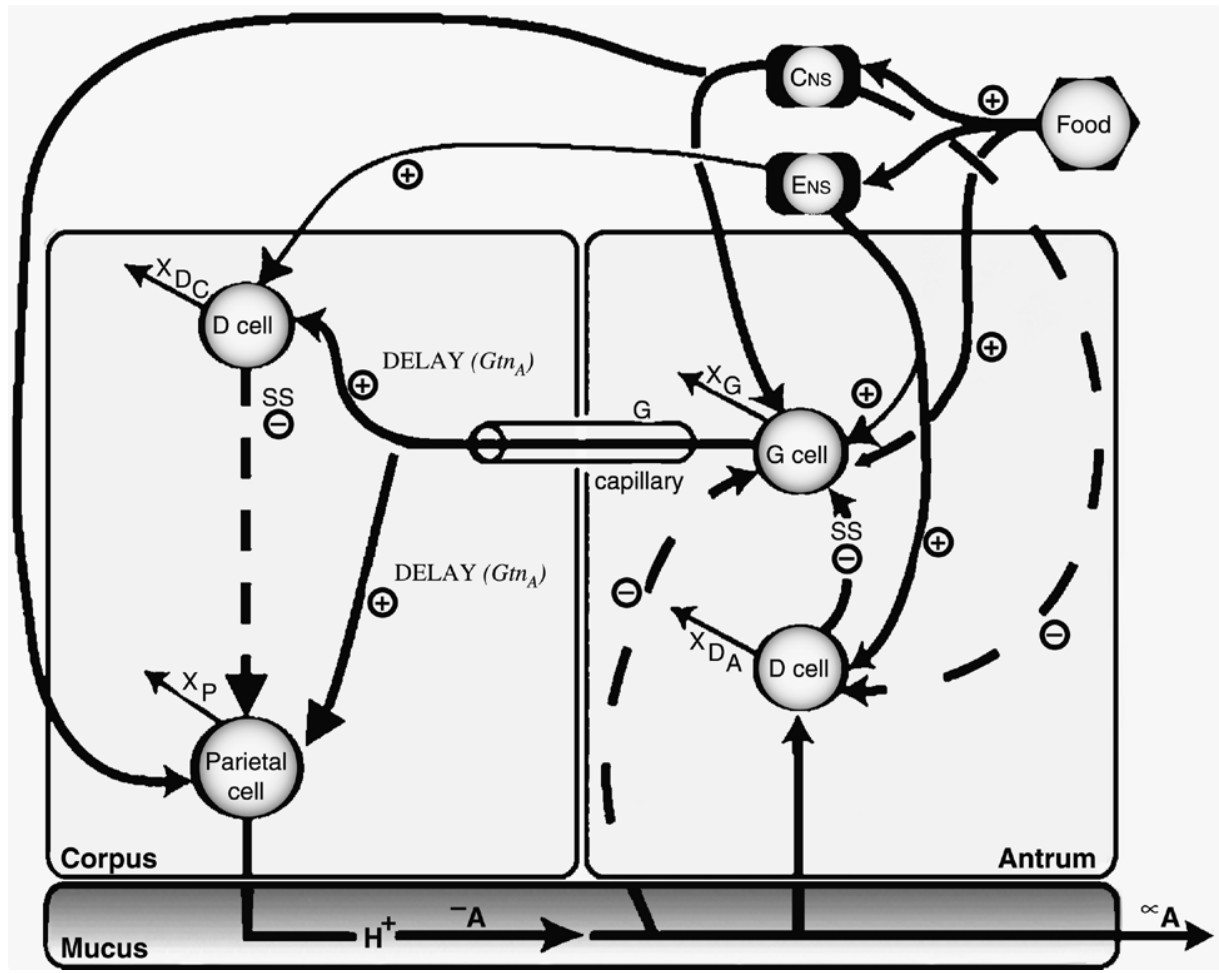

Figure 2. Model diagram of hormonal regulation of gastric acid secretion: the DDE model. The model includes positive and negative hormonal feedback systems pertinent to the secretion of gastric acid, and illustrates where the delay term arises. The cells are assigned to the respective compartments. G cells found in the antrum secrete gastrin $\left(G t n_{A}\right)$, the primary hormonal stimulus of gastric acid secretion. Gastrin stimulates gastric acid $\left(\mathrm{H}^{+}\right)$ and somatostatin (SS) secretion in the corpus, but there is a delay between its secretion in the antrum and these effects in the corpus. The Greek symbols represent the rates at which events occur. $\beta_{A}$ represents the rate of transport of acid. $\lambda$ symbolizes the death rate of a given cell type specified by the subscript. $\kappa_{A}$ corresponds to the washout rate of acid with A gastric emptying. Also shown are the central and enteric neural stimuli (CNS and ENS) supplied to the physiological system upon feeding. (Solid arrows represent positive stimuli whereas dashed arrows represent negative stimuli. The weight of arrows indicates the relative intensity of the stimulus.)

The resulting DDE model is illustrated in Fig. 2. The new DDE system is comprised of only 15 equations, with the following new equations for corpus stem cells, corpus somatostatin and corpus gastric acid, respectively:

Corpus stem cells.

$$
\begin{aligned}
\frac{d C_{s c}(t)}{d t}= & \left(\gamma_{\mathrm{Csc}}\right)\left(C_{s c}(t)\right)\left(C_{\mathrm{Csc}}-C_{s c}(t)\right)+\left(\frac{g_{\max }\left[\int_{t-\tau}^{t} f\left(G t n_{A}(t)\right) d t\right]^{2}}{\left[\int_{t-\tau}^{t} f\left(G t n_{A}(t)\right) d t\right]^{2}+\alpha_{\mathrm{Csc}}^{2}}\right) \\
& \times C_{s c}(t)-\left(p_{E}(t)+p_{D_{C}}(t)+p_{P}(t)\right)\left(\eta_{C s c}\right)\left(C_{s c}(t)\right) .
\end{aligned}
$$


Corpus somatostatin.

$$
\begin{aligned}
\frac{d\left[S_{C}(t)\right]}{d t}= & D_{C}(t)\left(\frac{K_{N S}\left[N_{E}(t)\right]}{\left(\left[N_{E}(t)\right]+\alpha_{N S}\right)\left(1+\frac{\left[S_{C}(t)\right]}{k_{S S}}\right)\left(1+\frac{\left[N_{C}(t)\right]}{k_{N S}}\right)}\right) \\
& +D_{C}(t)\left(\frac{K_{G S} \int_{t-\tau}^{t} f\left(G t n_{A}(t)\right) d t}{\left(\int_{t-\tau}^{t} f\left(G t n_{A}(t)\right) d t+\alpha_{G S}\right)\left(1+\frac{\left[S_{C}(t)\right]}{k_{S S}}\right)\left(1+\frac{\left[N_{C}(t)\right]}{k_{N S}}\right)}\right) \\
& -\kappa_{S}\left[S_{C}(t)\right] .
\end{aligned}
$$

Corpus gastric acid.

$$
\begin{aligned}
\frac{d\left[A_{C}(t)\right]}{d t}= & P(t)\left(\left(\frac{K_{N A}\left[N_{C}(t)\right]}{\left(\left[N_{C}(t)\right]+\alpha_{N A}\right)\left(1+\frac{\left[S_{C}(t)\right]}{k_{S A}}\right)}\right)\right. \\
& \left.+\left(\frac{K_{G A} \int_{t-\tau}^{t} f\left(G t n_{A}(t)\right) d t}{\left(\int_{t-\tau}^{t} f\left(G t n_{A}(t)\right) d t+\alpha_{G A}\right)\left(1+\frac{\left[S_{C}(t)\right]}{k_{S A}}\right)}\right)\right) \\
& -h b\left[A_{c}\right]\left[B_{c}\right]-\left[A_{C}(t)\right] \frac{k_{f \max } F d(t)}{F d(t)+\alpha_{F A}}-\beta_{A}\left[A_{C}(t)\right] .
\end{aligned}
$$

Different delay functions. The delay term $\int_{t-\tau}^{t} f\left(G t n_{A}(t)\right) d t$ is a function of the past levels of antral gastrin over the interval $(t-\tau, t)$. We explored three different delay functions:

(a) The total amount of antral gastrin produced in the past $\tau$ min, i.e.,

$$
\int_{t-\tau}^{t} G t n_{A}(t) d t
$$

(b) the average amount of antral gastrin produced in the past $\tau$ min: i.e.,

$$
\frac{1}{\tau} \int_{t-\tau}^{t} G t n_{A}(t) d t
$$

(c) the percentage of the total amount of antral gastrin produced in the past $\tau$ min: i.e.,

$$
p_{1} \int_{t-\tau}^{t} G t n_{A}(t) d t \quad \text { and } \quad p_{2} \int_{t-\tau}^{t} G t n_{A}(t) d t
$$


with $p_{1}+p_{2}=1$, where $p_{1}$ represents the proportion of released gastrin that affects D cell secretion of somatostatin in the corpus, while $p_{2}$ represents the remaining proportion of gastrin that affects $\mathrm{P}$ cell secretion of corpus acid.

The first delay function (1.22) seems to be the most reasonable in terms of stomach physiology. In fact, the amount of gastrin released by $\mathrm{G}$ cells in the antrum diffuses gradually into the corpus and is then available to the $\mathrm{D}$ and parietal cells only after a certain time period. Thus, the total amount of gastrin released in the previous $\tau$ min that is already located in the corpus region is effectively inducing the secretion of somatostatin and acid. This is physiologically relevant as it in part describes the Hill kinetics (i.e., a critical concentration of gastrin is required before a 'surge' of its effect is observed).

We also explored the two other delay functions, (1.23) and (1.24). They are relatively similar to each other and allowed us to test different possible mechanisms governing the gastric acid secretion physiology. The choice of different values of $\tau$ as well as different delay functions is discussed in the next section.

Another simplification from the original DDE system that we consider is in regard to the cell populations. While studies of the long-term behavior of the system should examine cell population variations, for short-term studies and simulations such as those examined here (i.e., from 24 to $300 \mathrm{~h}$ ), it may be assumed that they remain constant. In fact, the previous ODE model simulations (Joseph et al., 2002) confirm that cell populations do not undergo any significant fluctuation over the short term. This leads us to implement the DDE system without the cell population equations [equations (1.1)-(1.7)], thus reducing the model to only eight equations. The variables referring to the seven cell populations are held constant at their initial condition values in the new DDE setting.

Solver details. We simulated the system by numerically solving the differential equations using suitable numerical methods. We chose MatLab's ODE15s solver for stiff systems to solve the system of differential equations over a $24 \mathrm{~h}$ period. The ODE15s function implements two important sub-classes of a variable-order general linear multistep or k-step method, i.e., the class of the backward differentiation formulae or BDF (also known as the Gear's method) and the numerical differentiation formulae (Lambert, 1991). They are classes of implicit linear k-step methods with region of absolute stability large enough to make them relevant to the problem of stiffness. The implementation of the delay function is performed by storing the past values of the numerical integration and calculating the integral for each step of the numerical approximation scheme by the trapezoidal rule over the interval $[(t-\tau), t]$.

Cell population experimental estimates, parameter values and initial conditions are shown in the Appendix and are based on the existing ODE model. The complete list of parameter values are found in Joseph et al. (2002). 


\section{RESULTS}

To explore the behavior of the delay model, we ran simulations with each of the three delay functions described in (1.22)-(1.24). For each delay function we further examined the results of using the following values for the delay length $\tau$ (measured in minutes): 3, 6, 9, 18, 21, 24, 30, 45, and 60. For each simulation we used the same set of parameter values used in Joseph et al. (2002), so that we could directly compare the results of the DDE model and the ODE model. In Joseph et al. (2002) is also addressed the comparison of virtual model simulations with real experimental data.

Our simulations showed that a delay length of $\tau=30$ min closely reproduces the behavior of the ODE model. We first examine time series plots of certain key variables in the model (plasma gastrin, somatostatin, and $\mathrm{HCl}$ ). All the simulations with the DDE model show that these variables peaked three times per day. They also show that as we increased $\tau$ the amplitudes of the peak levels of somatostatin and $\mathrm{HCl}$ also increased. We find that these amplitudes nearly matched those produced by the ODE model when $\tau=30 \mathrm{~min}$. The values of plasma gastrin, somatostatin, and $\mathrm{HCl}$ in this simulation are plotted in Fig. 3, along with the corresponding data from the ODE model simulation to illustrate the similarity between the two models.

It is not surprising that plasma gastrin levels are slightly lower in the DDE model than in the ODE model [Fig. 3(a)]. The ODE model includes both antral and corpus gastrin, whereas only antral gastrin is included in the DDE model. Recall that we formulated the DDE model by removing corpus gastrin from the ODE model and modeling its effects in the corpus with the delay term.

On the other hand, plasma $\mathrm{HCl}$ levels are slightly higher in the DDE model [Fig. 3c]. This may be explained by the manner in which the $\mathrm{HCl}$ production by the corpus parietal cells is upregulated by gastrin in the two models. In the ODE model, this upregulation is a function of corpus gastrin at the present time $t\left(G t n_{c}(t)\right)$ in equation (1.6). In the DDE model this is replaced with the delay term $\int_{t-\tau}^{t} G t n_{A}(t) d t$. Instead of using the value of corpus gastrin at time $t$, corpus $\mathrm{HCl}$ production is enhanced by the integral of antral gastrin over the entire time period $[t-\tau, t]$.

We can use the same reasoning to explain the higher levels of somatostatin in the DDE model [Fig. 3b], since gastrin also upregulates the production of somatostatin by corpus $\mathrm{D}$ cells. Moreover, the higher levels of $\mathrm{HCl}$ may also contribute to the higher levels of plasma somatostatin, since antral $\mathrm{HCl}$ upregulates the production of antral somatostatin by $\mathrm{D}$ cells.

The significance of the delay, $\tau$. Further evidence in favor of the choice of $\tau=$ 30 min is provided by comparing the stability of the solutions of the DDE and ODE models. This was done by examining the phase portraits of corpus $\mathrm{HCl}$ vs. antral gastrin from the various simulations (Figs 4 and 5). As expected, the ODE 

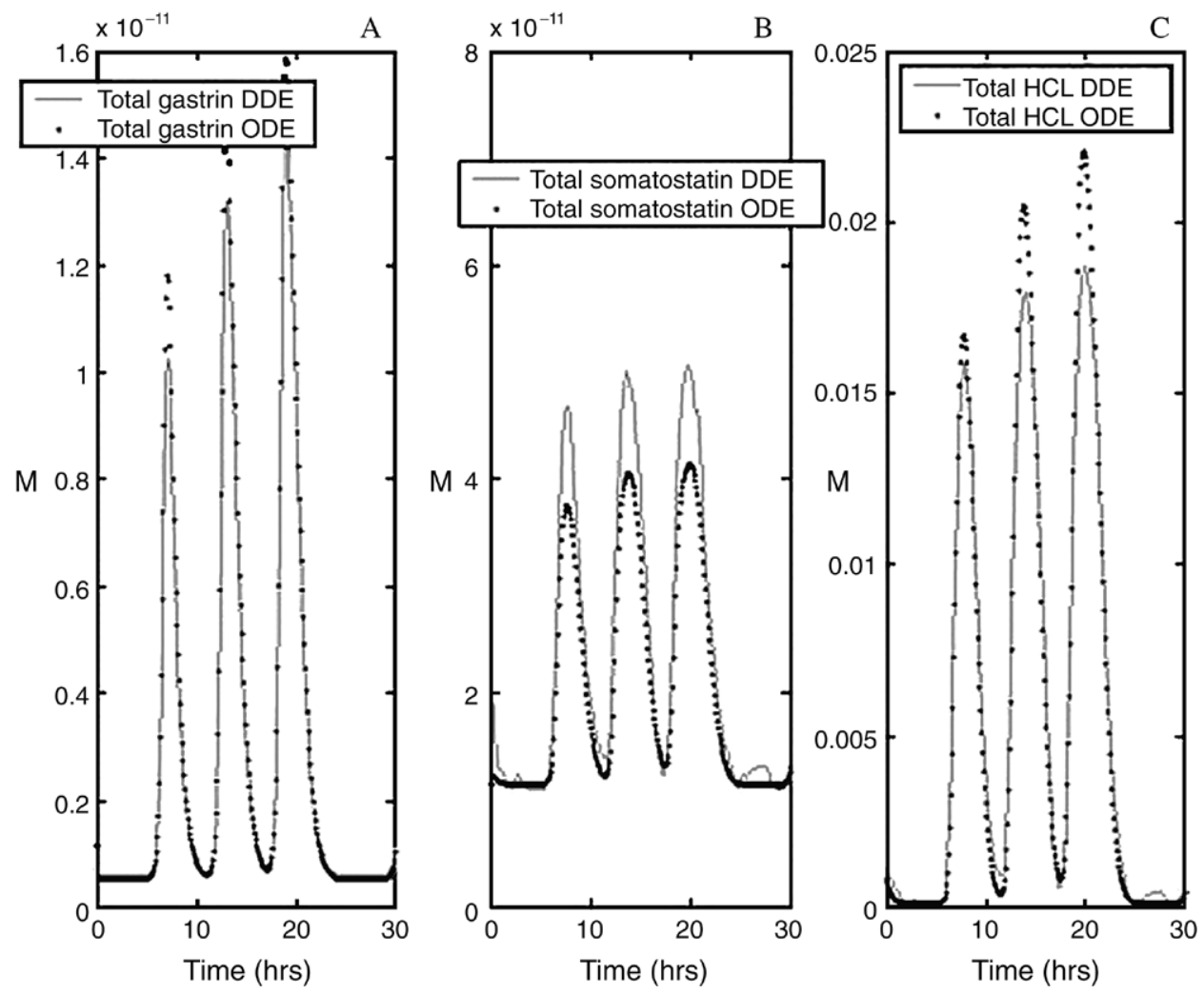

Figure 3. Time series of plasma gastrin, plasma somatostatin, and plasma $\mathrm{HCl}$, from ODE and DDE simulations. Data from simulations of length $30 \mathrm{~h}$ of the ODE and DDE systems. Units for this and all subsequent figures: gastrin and somatostatin are measured in picomoles $(\mathrm{pM}) ; \mathrm{HCl}$ is measured in millimoles $(\mathrm{mM})$.

system produced stable period 3-limit cycles. The period here is about three times the period of the transit time around a single loop. If the DDE model is to be a good approximation of the ODE model, the phase portraits should be similar in terms of behavior and stability. The DDE model with $\tau=30$ min yields the phase portrait that (visually) most closely matches that of the ODE model, both in one day $(24 \mathrm{~h})$ and the short term $(300 \mathrm{~h})$ (see Fig. 4). We found that for smaller values of $\tau$, the phase plots were highly irregular, whereas for values of $\tau$ greater than or equal to $30 \mathrm{~min}$, the phase plots closely resembled the stable limit cycles. This phenomenon was true regardless of which delay function was used (see Fig. 5).

We can explain these differences in the phase diagrams (Fig. 5) by first understanding the dynamics of gastrin-stimulated acid release. Gastrin levels above a certain threshold significantly increase acid secretion. Thus, as $\tau$ increases, the time to maximal secretion of acid decreases. Our results indicate that for values of $\tau$ greater or equal to $30 \mathrm{~min}$, gastrin transported to the corpus sufficiently stimulates 

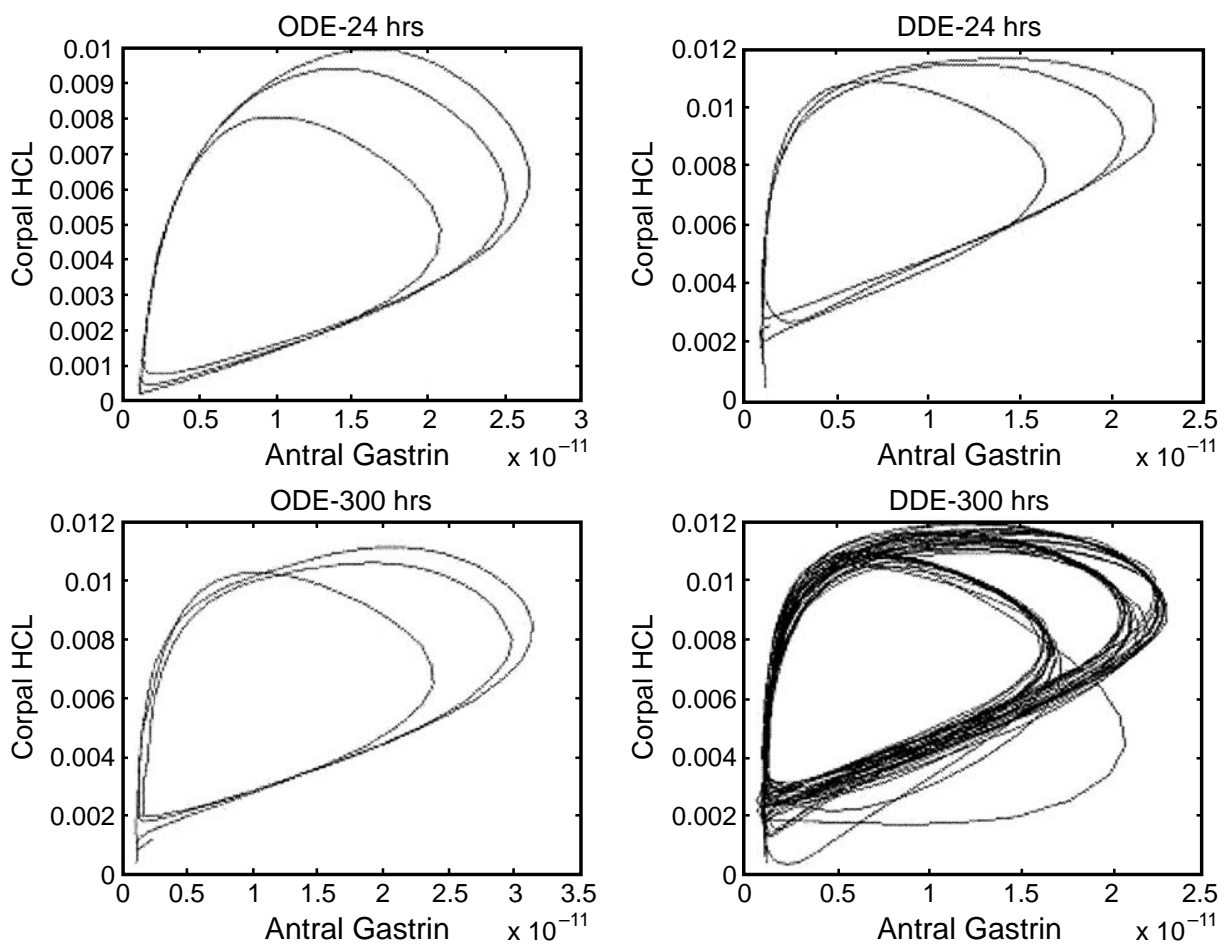

Figure 4. Phase portraits of antral gastrin vs. corpal $\mathrm{HCl}$, ODE and DDE. Phase portraits of antral gastrin vs. corpal $\mathrm{HCl}$ from simulations of the ODE system and the DDE system, for simulations of length 24 and $300 \mathrm{~h}$.

acid release maintaining acid profiles comparable to those observed with the ODE model. For values of $\tau$ significantly greater than 30 min we observed an increase in peak stimulated acid levels which we attribute to the incomplete clearance of gastrin from the system. Conversely, the irregularity of phase plots with smaller $\tau$ values (less than $10 \mathrm{~min}$ ) are explained by insufficient gastrin stimulation of acid as well as varying degrees of gastrin clearance. In addition we include some sensitivity analysis results from the ODE model (see the Appendix). We also note that from the ODE model, the transport rate of gastrin from antrum to corpus is important in determining the acid level outcome, further strengthening our DDE model formulation.

In summary, although some differences are expected from replacing the ODE model with the DDE model, they do not affect the overall picture. We find the behavior of the DDE model to be qualitatively similar to that of the ODE model. Indeed, the quantitative differences described above between simulations of the two models are so slight that they could be accounted for by individual variations. Thus, the dynamics of the two systems could be considered overlapping.

As mentioned above, when we consider gastric acid secretion over a short time period $(<300 \mathrm{~h})$, the cell populations do not undergo any significant fluctuations 

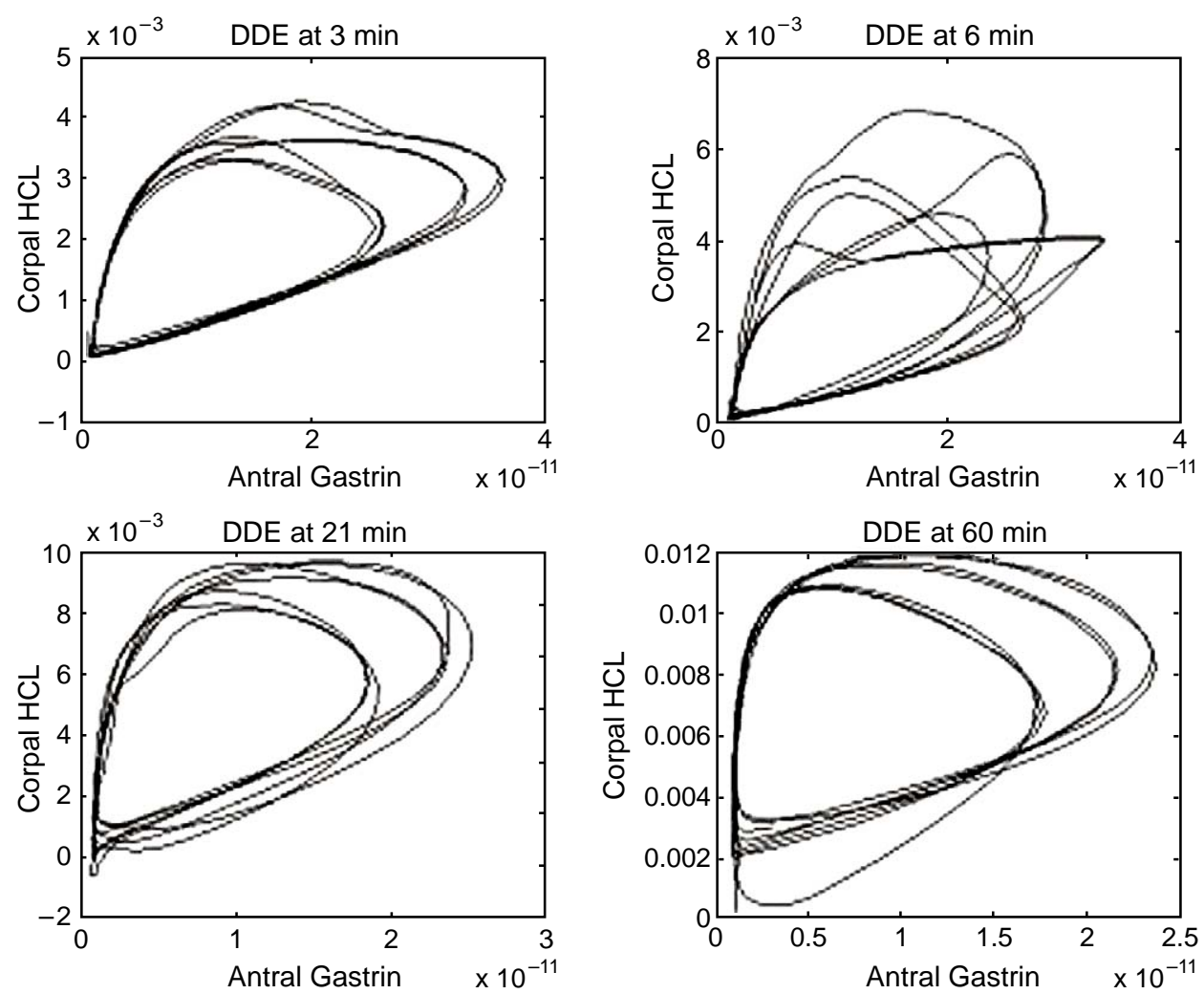

Figure 5. Phase portraits of antral gastrin vs. corpal $\mathrm{HCl}$, 'total amount' delay function. Phase portraits of antral gastrin vs. corpal $\mathrm{HCl}$ from simulations of the DDE system with the total amount of gastrin produced in the past $\tau$ min used as the delay function, for values of $\tau=3,6,21$ and $60 \mathrm{~min}$.

and can be treated as constants. We examined the resulting eight equation DDE model and found that the results are similar to the 15 equation DDE model discussed above (data not shown). Thus, for short-term simulations we have replaced an 18-equation system of ODEs with an 8-equation system of DDEs.

Virtual depletion experiment. A common wet-lab experimental method is to consider an animal model in which a specific element is deleted from the animal's system at birth (via 'gene knockout') or removed at a specific time (using a protein that binds and removes the specific element). To validate the ODE model a number of virtual depletion experiments were examined (Joseph et al., 2002), in which a particular variable was held constant at zero through the course of a simulation to test how the system was affected by the absence of that element. These simulations were then compared with experimental data. To further compare our DDE model with the ODE model, we repeated the virtual depletion experiments with respect to antral gastrin, corpus somatostatin, and 

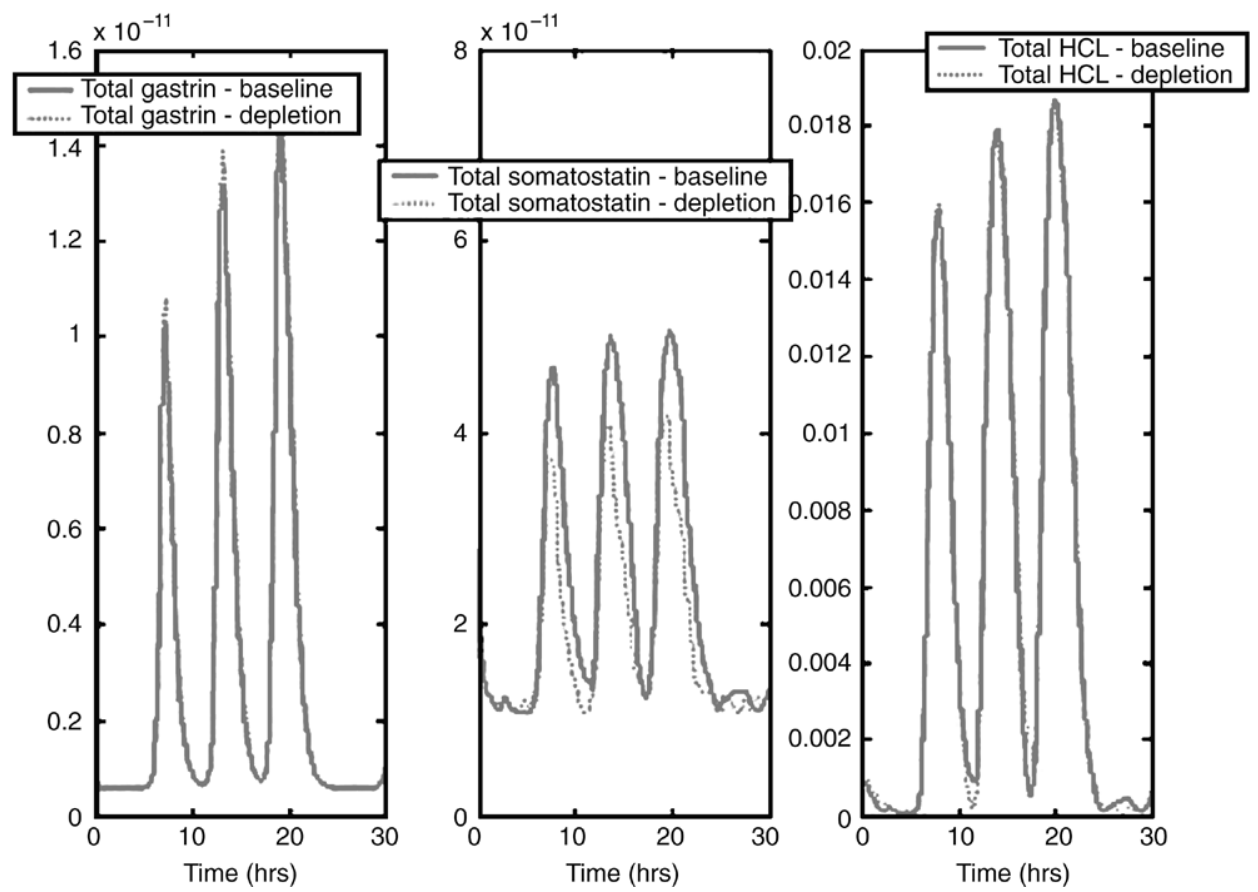

Figure 6. Antral somatostatin depletion. Data from virtual depletion of antral somatostatin from the DDE system. Data from baseline simulation of DDE system (i.e., with no depletion) is shown for comparison.

antral somatostatin; we compared these with the baseline simulations of the DDE model.

First consider the somatostatin depletion experiments, shown in Fig. 6. Depletion of antral somatostatin results in slightly increased levels of gastrin, since antral somatostatin inhibits $\mathrm{G}$ cell production of gastrin in the antrum. But this has a negligible effect on the levels of plasma $\mathrm{HCl}$, which are roughly equal to the baseline simulation. By contrast, the depletion of corpus somatostatin (Fig. 7) leads to much higher peak levels of plasma $\mathrm{HCl}$, when compared to the baseline simulation. This is to be expected, since corpus somatostatin is the only inhibitor of $\mathrm{HCl}$ production in the model.

Finally, depletion of antral gastrin (Fig. 8) decreases the levels of both plasma somatostatin and plasma $\mathrm{HCl}$. This can be explained as a consequence of gastrin (via the delay term) upregulating the production of both somatostatin and $\mathrm{HCl}$ in the corpus. Moreover, the reduced levels of $\mathrm{HCl}$ also leads to lower levels of antral somatostatin, since $\mathrm{HCl}$ stimulates $\mathrm{D}$ cell production of somatostatin in the antrum.

It is interesting to note that although corpus somatostatin inhibits the stimulatory effects of both gastrin and the CNS on parietal cell production of $\mathrm{HCl}$, the lower levels of corpus somatostatin do not lead to higher levels of $\mathrm{HCl}$. We may conclude 

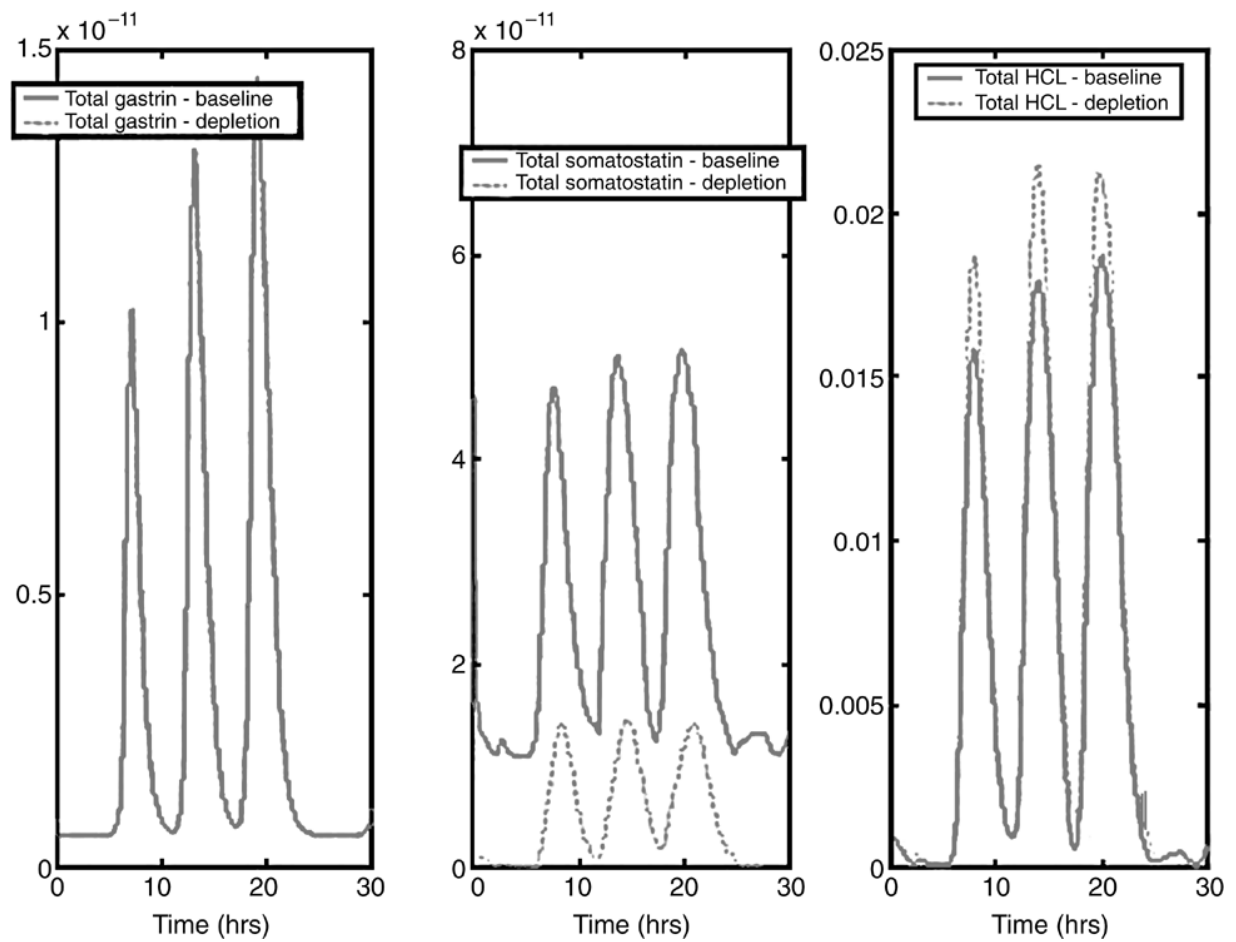

Figure 7. Corpal somatostatin depletion. Data from virtual depletion of corpal somatostatin from the DDE system. As in Fig. 8, data from baseline simulation of the DDE system is shown for comparison.

that the reduced inhibition of CNS stimulation of $\mathrm{HCl}$ production does not overcome the total lack of gastrin stimulation of $\mathrm{HCl}$ production. Thus, this depletion experiment further confirms that gastrin is essential for maintaining adequate levels of $\mathrm{HCl}$.

\section{DISCUSSION}

In this paper we have re-examined an existing model of human gastric acid secretion consisting of 18 nonlinear ODEs. We simplified the model to an 8-equation system, introducing a distributed delay to describe the physiological feature of the process. Recent studies in mathematical biology have also taken a similar approach, incorporating delays into previously published ODE models, trying to preserve the qualitative and quantitative properties of the existing system (such as stability). Although not many models have been implemented as DDE, delays occur naturally in biological phenomena and a DDE formulation is often more biologically intuitive than its counterpart ODE model. Examples can be found in the context of HIV modeling (Tam, 1999; Culshaw and Ruan, 2000), glucose insulin regulatory system (De Gaetano and Arino, 2000), gene expression 

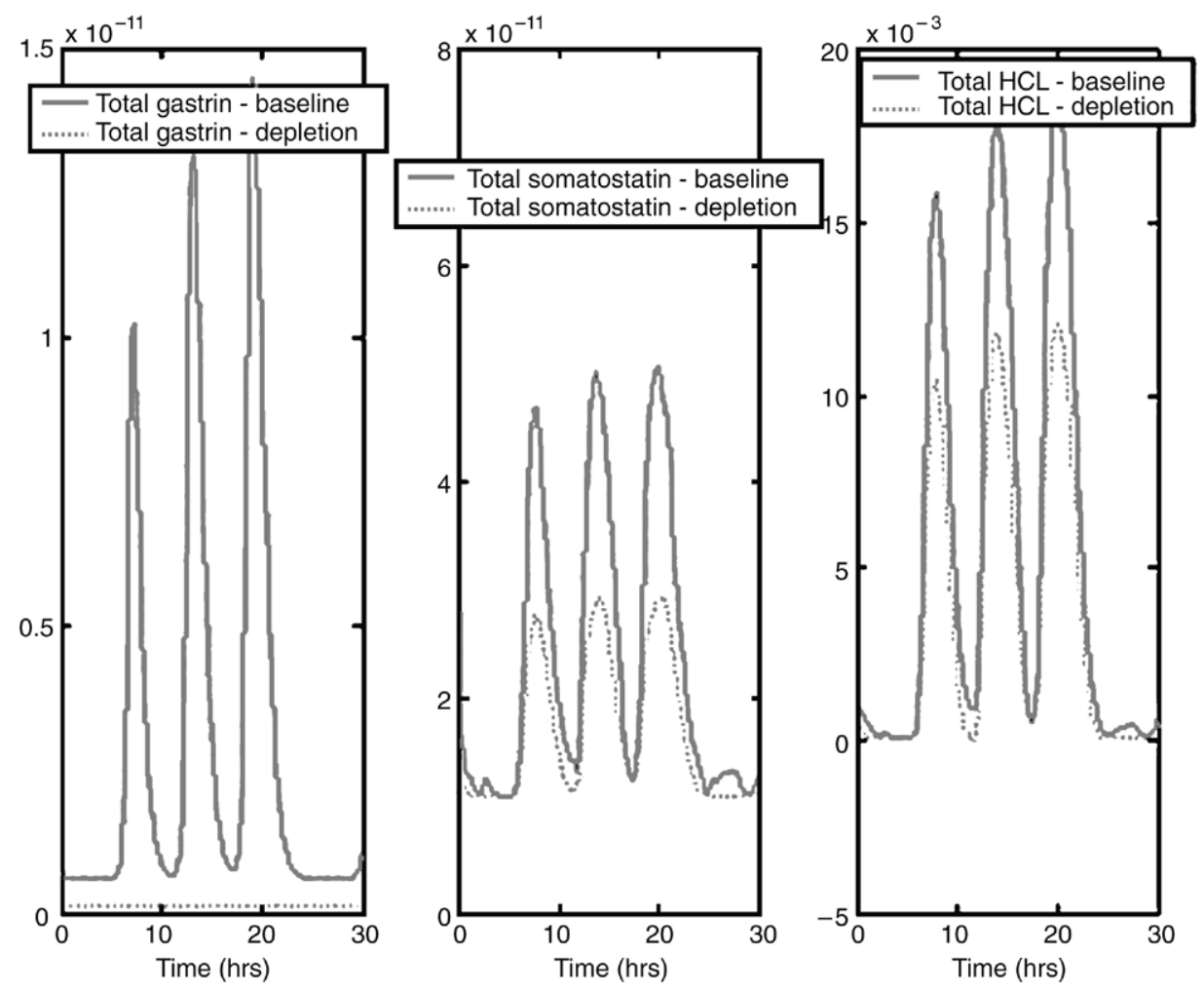

Figure 8. Antral gastrin depletion. Data from virtual depletion of antral gastrin from the DDE system. As in the previous two figures, data from baseline simulation of DDE system is shown for comparison.

(Chen et al., 1999b) and cell cycle (Busenberg and Tang, 1994), as well as in various other fields (Kuang, 1993; Murray, 2001).

We have shown that:

(1) the temporal behavior of the DDE model closely reproduces that of the ODE model;

(2) the stability of the ODE system is also observed in the DDE model at a delay length of $\tau=30 \mathrm{~min}$, which is physiologically consistent;

(3) virtual depletion experiments further validate that the DDE model replicates the behavior of the ODE system.

Gastrin is secreted by $\mathrm{G}$ cells in the antrum and diffuses into the underlying blood capillaries. In the corpus, transported gastrin diffuses back into the extracellular spaces where it is able to stimulate ECL and parietal cells. The transport time of gastrin between the antrum and the corpus is a rapid process (much less than $30 \mathrm{~min})$. 
Time delays also occur during gastrin stimulation of ECL and parietal cells. Although the binding of gastrin to its receptor is a rapid process, a delay is observed before a significant local concentration of gastrin can be accumulated around ECL and parietal cells to elicit histamine and acid release respectively. Furthermore, before gastrin can evoke acid release, secreted histamine must diffuse from the ECL cell towards the parietal cell. At the parietal cell, histamine stimulates acid release and also amplifies the effects of gastrin on the parietal cell. Physiologically, these processes can account for the 30 min delay observed prior to a peak in gastric acid levels (Chew and Hersey, 1982). While we argue that a delay period less than 30 min may result in sub-threshold gastrin concentrations for acid stimulation, we cannot neglect the negative feedback system represented by somatostatin. In simulations with values less than $30 \mathrm{~min}$, it is feasible that somatostatin released short-circuits acid release. Overall these findings lead us to suggest that an intrinsic inter-compartmental delay in gastrin transport is important in maintaining acid homeostasis.

\section{APPENDiX}

\section{Feeding function.}

$$
\begin{aligned}
F d(t)= & 8(1+\tanh (\pi[t-(24 q r s+19)])) e^{-\frac{1}{2}(1+3.5[t-(24 q r s+19)])} \\
& +5(1+\tanh (\pi[t-(24 q r s+13)])) e^{-\frac{1}{2}(1+3.5[t-(24 q r s+13)])} \\
& +2(1+\tanh (\pi[t-(24 q r s+7)])) e^{-\frac{1}{2}(1+3.5[t-(24 q r s+7)])}
\end{aligned}
$$

where $q r s=$ floor $\left(\frac{t}{24}\right)$

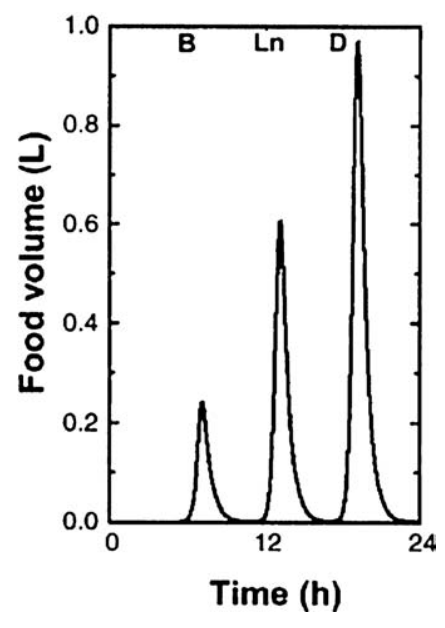




\section{PARAMETER LIST}

\begin{tabular}{|c|c|c|c|}
\hline \multicolumn{4}{|c|}{ CELL POPULATIONS } \\
\hline Cell type & $\begin{array}{l}\text { Steady state } \\
\text { simulated } \\
\text { cell numbers } \\
\text { (cells/stomach) }\end{array}$ & $\begin{array}{l}\text { Immunohistochemistry } \\
\text { estimates } \\
\text { (cells/stomach) }\end{array}$ & Published data \\
\hline $\mathrm{G}$ cells & $8.75 \times 10^{6}$ & $23.82 \times 10^{6} \pm 14.44 \times 10^{6}$ & $\begin{array}{l}8.0-15 \times 10^{6} \text { (Royston et al., } \\
1978), 15.5 \times 10^{6}(\mathrm{dogs}) \\
(\text { Nomiyama et al., } 1981), \\
16.6 \times 10^{6} \text { (dogs) (Takahashi } \\
\text { et al., 1979) }\end{array}$ \\
\hline Antral D cells & $3.70 \times 10^{6}$ & $9.53 \times 10^{6} \pm 5.77 \times 10^{6}$ & $\begin{array}{l}\text { G/D cells ratio of } 2: 1 \\
\left(\text { Solcia } \text { et al., 1986), } 11 \times 10^{6}\right. \\
(\text { dogs })(\text { Nomiyama } \text { et al., } 1981)\end{array}$ \\
\hline ECL cells & $8.68 \times 10^{8}$ & NA & $\begin{array}{l}30 \% \text { total endocrine cell popula- } \\
\text { tion (humans) (Helander et al., } \\
1992 \text { ); (D'Adda et al., 1989); } \\
35 \% \text { (Simonsson et al., 1988); } \\
8.81 \times 10^{6} \text { (rats) }\end{array}$ \\
\hline Corpus D cell & $2.69 \times 10^{8}$ & $2.61 \times 10^{8} \pm 0.83 \times 10^{8}$ & $\begin{array}{l}4 \times 10^{6}(\mathrm{dogs}) \text { (Nomiyama et al., } \\
1981)\end{array}$ \\
\hline Parietal cells & $1.00 \times 10^{9}$ & $1.09 \times 10^{9} \pm 2.4 \times 10^{8}$ & $\begin{array}{l}1.005 \times 10^{9} \text { (humans) (Naik } \\
\text { et al., 1971) }\end{array}$ \\
\hline
\end{tabular}

\section{INITIAL CONDITIONS}

\begin{tabular}{llc}
\hline $\begin{array}{l}\text { Initial } \\
\text { conditions }\end{array}$ & Descriptions & Parameter value \\
\hline Osc $(0)$ & Initial corpus stem cell population & $3.8700 \times 10^{7}$ cells \\
Psc $(0)$ & Initial antral stem cell populations & $1.20 \times 10^{6}$ cells \\
Gc(0) & Initial G cell population & $8.7525 \times 10^{6}$ cells \\
$\operatorname{Dox}(0)$ & Initial corpus D cell population & $2.6934 \times 10^{8}$ cells \\
$\operatorname{Dp}(0)$ & Initial antral D cell population & $3.6936 \times 10^{6}$ cells \\
$\operatorname{Ec}(0)$ & Initial ECL cell population & $8.6844 \times 10^{8}$ cells \\
Oc(0) & Initial parietal cell population & $1.005 \times 10^{9}$ cells \\
{$[\operatorname{Gp}(0)]$} & Initial antral gastrin concentration & $1.0213 \mathrm{pM}$ \\
{$[\operatorname{Gox}(0)]$} & Initial corpus gastrin concentration & $0.1289 \mathrm{pM}$ \\
{$[\operatorname{Sp}(0)]$} & Initial antral somatostatin concentration & $8.4402 \mathrm{pM}$ \\
{$[\operatorname{Sox}(0)]$} & Initial corpus somatostatin concentration & $66.56 \mathrm{pM}$ \\
{$[\operatorname{Hox}(0)]$} & Initial histamine concentration & $1.1074 \mathrm{nM}$ \\
{$[\operatorname{PoxA}(0)]$} & Initial corpus acid concentration & $10.9 \mathrm{mM}$ \\
{$[\operatorname{PpA}(0)]$} & Initial antral acid concentration & $0.2605 \mathrm{mM}$ \\
{$[\operatorname{Reg}(0)]$} & Initial CNS effector concentration & $0.57309 \mathrm{nM}$ \\
{$[\operatorname{RegB}(0)]$} & Initial ENS effector concentration & $55.588 \mathrm{pM}$ \\
{$[\operatorname{bicA}(0)]$} & Initial antral bicarbonate concentration & $2.8818 \mu \mathrm{M}$ \\
{$[\operatorname{bicC}(0)]$} & Initial corpus bicarbonate concentration & $0.1059 \mathrm{mM}$ \\
\hline
\end{tabular}




\begin{tabular}{|c|c|c|c|c|}
\hline \multicolumn{5}{|c|}{ PARAMETERS } \\
\hline Parameter & Description & Values & References & Unit \\
\hline$K_{N G 1}$ & $\begin{array}{l}\text { Maximal secretion rate } \\
\text { of gastrin due to ENS } \\
\text { stimulation per cell }\end{array}$ & $6.28 \times 10^{-17}$ & $\begin{array}{l}\text { Holst et al. } \\
(1987), \text { Nishi } \\
\text { et al. (1985) } \\
\text { and Campos } \\
\text { et al. (1990) }\end{array}$ & $\mathrm{M} \mathrm{h}^{-1}$ cell $^{-1}$ \\
\hline$K_{N G 2}$ & $\begin{array}{l}\text { Maximal secretion rate } \\
\text { of gastrin due to CNS } \\
\text { stimulation per cell }\end{array}$ & $8.75 \times 10^{-17}$ & $\begin{array}{l}\text { Matsuno et al. } \\
\text { (1997) }\end{array}$ & $\mathrm{M} \mathrm{h}^{-1}$ cell $^{-1}$ \\
\hline$K_{F G}$ & $\begin{array}{l}\text { Maximal secretion rate } \\
\text { of gastrin due to ENS } \\
\text { stimulation per cell }\end{array}$ & $9.39 \times 10^{-18}$ & Estimated & $\mathrm{Mh}^{-1}$ cell $^{-1}$ \\
\hline$\alpha_{N G 1}$ & $\begin{array}{l}\text { Concentration of ENS } \\
\text { stimulant at which rate of } \\
\text { gastrin secretion is } 50 \%\end{array}$ & $1.0 \times 10^{-10}$ & $\begin{array}{l}\text { Holst et al. } \\
(1987)\end{array}$ & M \\
\hline$\alpha_{N G 2}$ & $\begin{array}{l}\text { Intensity of the regulator } \\
\text { at which rate of gastrin } \\
\text { secretion is } 50 \%\end{array}$ & $1.0 \times 10^{-10}$ & $\begin{array}{l}\text { Holst et al. } \\
(1987)\end{array}$ & M \\
\hline$k_{S G}$ & $\begin{array}{l}\text { Dissociation constant of } \\
\text { somatostatin from som- } \\
\text { atostatin receptor }\end{array}$ & $9.0 \times 10^{-11}$ & $\begin{array}{l}\text { Rocheville } \\
\text { et al. }(2000)\end{array}$ & M \\
\hline$\kappa_{G}$ & Clearance rate of gastrin & 11.88 & $\begin{array}{l}\text { Hansen et al. } \\
\text { (1996) }\end{array}$ & $\mathrm{h}^{-1}$ \\
\hline$\beta_{G}$ & $\begin{array}{l}\text { Transport rate of gastrin } \\
\text { from the antrum to cor- } \\
\text { pus regions }\end{array}$ & 1.5 & Estimated & $\mathrm{h}^{-1}$ \\
\hline$K_{A S}$ & $\begin{array}{l}\text { Maximal rate of secre- } \\
\text { tion of somatostatin due } \\
\text { to stimulation with ant- } \\
\text { rum acid }\end{array}$ & $8.04 \times 10^{-15}$ & Estimated & $\mathrm{M} \mathrm{h}^{-1}$ cell $^{-1}$ \\
\hline$K_{G S}$ & $\begin{array}{l}\text { Maximal rate of secre- } \\
\text { tion of corpal somato- } \\
\text { statin due to stimulation } \\
\text { with antral gastrin }\end{array}$ & $2.54 \times 10^{-18}$ & $\begin{array}{l}\text { Schubert et al. } \\
\text { (1987) }\end{array}$ & $\mathrm{M} \mathrm{h}^{-1}$ cell $^{-1}$ \\
\hline$\alpha_{A S}$ & $\begin{array}{l}\text { Acid concentration at } \\
\text { which the rate of somato- } \\
\text { statin secretion is half } \\
\text { maximal }\end{array}$ & 0.05 & $\begin{array}{l}\text { Makhlouf } \\
\text { and Schubert } \\
(1990)\end{array}$ & M \\
\hline$\alpha_{G S}$ & $\begin{array}{l}\text { Gastrin concentration at } \\
\text { which the rate of somato- } \\
\text { statin secretion is half } \\
\text { maximal }\end{array}$ & $5.20 \times 10^{-12}$ & $\begin{array}{l}\text { Schubert et al. } \\
\text { (1987) }\end{array}$ & M \\
\hline$k_{N S}$ & $\begin{array}{l}\text { Dissociation constant of } \\
\text { GRP from receptors on D } \\
\text { cells }\end{array}$ & $1.0 \times 10^{-9}$ & $\begin{array}{l}\text { Schaffer et al. } \\
\text { (1997) }\end{array}$ & M \\
\hline
\end{tabular}




\begin{tabular}{|c|c|c|c|c|}
\hline \multicolumn{5}{|c|}{ PARAMETERS } \\
\hline Parameter & Description & Values & References & Unit \\
\hline$\kappa_{S}$ & $\begin{array}{l}\text { Clearance rate of som- } \\
\text { atostatin }\end{array}$ & 13.86 & $\begin{array}{l}\text { Hildebrand } \\
\text { et al. (1994) }\end{array}$ & $\mathrm{h}^{-1}$ \\
\hline$K_{N S 1}$ & $\begin{array}{l}\text { Maximal rate of secre- } \\
\text { tion of antral somato- } \\
\text { statin due to enteric ner- } \\
\text { vous stimulus }\end{array}$ & $1.14 \times 10^{-15}$ & $\begin{array}{l}\text { Schaffer et al. } \\
\text { (1997), Holst } \\
\text { et al. (1987) }\end{array}$ & $\mathrm{M} \mathrm{h}^{-1}$ cell $^{-1}$ \\
\hline$K_{N S 2}$ & $\begin{array}{l}\text { Maximal rate of secre- } \\
\text { tion of corpal somato- } \\
\text { statin due to enteric ner- } \\
\text { vous stimulus }\end{array}$ & $1.54 \times 10^{-17}$ & $\begin{array}{l}\text { Schaffer et al. } \\
\text { (1997) }\end{array}$ & $\mathrm{M} \mathrm{h}^{-1}$ cell $^{-1}$ \\
\hline$\alpha_{N S 1}$ & $\begin{array}{l}\text { Concentration of the } \\
\text { ENS stimulant at which } \\
\text { the rate of antral somato- } \\
\text { statin secretion is half } \\
\text { maximal }\end{array}$ & $6.28 \times 10^{-7}$ & Estimated & M \\
\hline$\alpha_{N S 2}$ & $\begin{array}{l}\text { Concentration of the } \\
\text { ENS stimulant at which } \\
\text { the rate of corpal somato- } \\
\text { statin secretion is half } \\
\text { maximal }\end{array}$ & $8.98 \times 10^{-11}$ & Estimated & M \\
\hline
\end{tabular}

\begin{tabular}{|c|c|c|c|c|}
\hline \multicolumn{5}{|c|}{ SENSITIVITY ANALYSIS } \\
\hline Parameter & Definition & Range & $\begin{array}{l}\text { Strong effect } \\
\text { on the system }\end{array}$ & Units \\
\hline$N_{\max 1}$ & Maximal CNS activity rate & $\begin{array}{l}{\left[1 \times 10^{-5}\right.} \\
\left.1 \times 10^{-2}\right]\end{array}$ & $\bullet$ & $\mathrm{M} \mathrm{h}^{-1}$ \\
\hline$N_{\max 2}$ & Maximal ENS activity rate & $\begin{array}{l}{\left[1 \times 10^{-8}\right.} \\
\left.1 \times 10^{-5}\right]\end{array}$ & & $\mathrm{M} \mathrm{h}^{-1}$ \\
\hline$K_{N G 1}$ & $\begin{array}{l}\text { Maximal gastrin secretion } \\
\text { rate due to CNS stimula- } \\
\text { tion }\end{array}$ & $\begin{array}{l}{\left[6.28 \times 10^{-19}\right.} \\
\left.6.28 \times 10^{-16}\right]\end{array}$ & $\bullet$ & $\mathrm{M} \mathrm{h}^{-1}$ cell $^{-1}$ \\
\hline$K_{N G 2}$ & $\begin{array}{l}\text { Maximal gastrin secretion } \\
\text { rate due to CNS stimula- } \\
\text { tion }\end{array}$ & $\begin{array}{l}{\left[8.75 \times 10^{-19}\right.} \\
\left.8.75 \times 10^{-16}\right]\end{array}$ & & $\mathrm{M} \mathrm{h}^{-1}$ cell $^{-1}$ \\
\hline$K A S$ & $\begin{array}{l}\text { Maximal somatostatin } \\
\text { secretion rate due to acid } \\
\text { stimulation }\end{array}$ & $\begin{array}{l}{\left[1.54 \times 10^{-19}\right.} \\
\left.1.54 \times 10^{-16}\right]\end{array}$ & & $\mathrm{M} \mathrm{h}^{-1}$ cell $^{-1}$ \\
\hline$K_{N S}$ & $\begin{array}{l}\text { Maximal somatostatin } \\
\text { secretion rate due to ENS } \\
\text { stimulation }\end{array}$ & $\begin{array}{l}{\left[4.03 \times 10^{-17}\right.} \\
\left.4.03 \times 10^{-14}\right]\end{array}$ & & $\mathrm{M} \mathrm{h}^{-1}$ cell $^{-1}$ \\
\hline$K_{N H}$ & $\begin{array}{l}\text { Maximal histamine secre- } \\
\text { tion rate due to ENS stim- } \\
\text { ulation }\end{array}$ & $\begin{array}{l}{\left[7.59 \times 10^{-17}\right.} \\
\left.7.59 \times 10^{-14}\right]\end{array}$ & & $\mathrm{M} \mathrm{h}^{-1}$ cell $^{-1}$ \\
\hline
\end{tabular}




\begin{tabular}{|c|c|c|c|c|}
\hline \multicolumn{5}{|c|}{ SENSITIVITY ANALYSIS } \\
\hline Parameter & Definition & Range & $\begin{array}{l}\text { Strong effect } \\
\text { on the system }\end{array}$ & Units \\
\hline$K_{G H}$ & $\begin{array}{l}\text { Maximal histamine secre- } \\
\text { tion rate due to gastrin stim- } \\
\text { ulation }\end{array}$ & $\begin{array}{l}{\left[7.77 \times 10^{-17}\right.} \\
\left.7.77 \times 10^{-14}\right]\end{array}$ & & $\mathrm{M} \mathrm{h}^{-1}$ cell $^{-1}$ \\
\hline$K_{N A}$ & $\begin{array}{l}\text { Maximal acid secretion rate } \\
\text { due to CNS stimulation }\end{array}$ & $\begin{array}{l}{\left[2.33 \times 10^{-13}\right.} \\
\left.2.33 \times 10^{-10}\right]\end{array}$ & & $\mathrm{M} \mathrm{h}^{-1}$ cell $^{-1}$ \\
\hline$K_{G A}$ & $\begin{array}{l}\text { Maximal acid secretion rate } \\
\text { due to gastrin stimulation }\end{array}$ & $\begin{array}{l}{\left[4.98 \times 10^{-13},\right.} \\
\left.4.98 \times 10^{-10}\right]\end{array}$ & & $\mathrm{M} \mathrm{h}^{-1}$ cell $^{-1}$ \\
\hline$K_{H A}$ & $\begin{array}{l}\text { Maximal acid secretion rate } \\
\text { due to histamine stimula- } \\
\text { tion }\end{array}$ & $\begin{array}{l}{\left[8.96 \times 10^{-13}\right.} \\
\left.8.96 \times 10^{-10}\right]\end{array}$ & & $\mathrm{M} \mathrm{h}^{-1}$ cell $^{-1}$ \\
\hline$k_{A G}$ & $\begin{array}{l}\text { Dissociation constant of the } \\
\text { effect of acid on gastrin } \\
\text { secretion }\end{array}$ & {$[0.0001,0.1]$} & & M \\
\hline$k_{S H}$ & $\begin{array}{l}\text { Dissociation constant of the } \\
\text { somatostatin from somato- } \\
\text { statin receptors on ECL } \\
\text { cells }\end{array}$ & $\begin{array}{l}{\left[2.0 \times 10^{-12}\right.} \\
\left.2.0 \times 10^{-9}\right]\end{array}$ & & M \\
\hline$k_{S A}$ & $\begin{array}{l}\text { Dissociation constant of } \\
\text { somatostatin from somato- } \\
\text { statin receptors on parietal } \\
\text { cells }\end{array}$ & $\begin{array}{l}{\left[2.0 \times 10^{-12}\right.} \\
\left.2.0 \times 10^{-9}\right]\end{array}$ & & M \\
\hline$\beta_{G}$ & $\begin{array}{l}\text { Transport rate of gastrin } \\
\text { from antrum to corpus }\end{array}$ & {$[0.5,3.5]$} & $\bullet \bullet$ & $\mathrm{M} \mathrm{h}^{-1}$ \\
\hline
\end{tabular}

This table summarizes key parameters of the model. The $\bullet$ indicates those parameters that effect the oucome most significantly.

\section{REFERENCES}

Arnold, R., H. Koop, H. Schwarting, K. Tuch and B. Willemer (1986). Effect of acid inhibition on gastric endocrine cells. Scand. J. Gastroenterol Suppl. 125, 14-19.

Blair, A. J. d., C. T. Richardson, M. Vasko, J. H. Walsh and M. Feldman (1986). Comparison of acid secretory responsiveness to gastrin heptadecapeptide and of gastrin heptadecapeptide pharmacokinetics in duodenal ulcer patients and normal subjects. J. Clin. Invest. 78, 779-783.

Busenberg, S. and B. Tang (1994). Mathematical models of the early embryonic cell cycle: the role of MPF activation and cyclin degradation. J. Math. Biol. 32, 573-596.

Campos, R. V., A. M. Buchan, R. M. Meloche, R. A. Pederson, Y. N. Kwok and D. H. Coy (1990). Gastrin secretion from human antral G cells in culture. Gastroenterology 99, $36-44$.

Chen, D., C. M. Zhao, E. Lindstrom and R. Hakanson (1999a). Rat stomach ECL cells up-date of biology and physiology. Gen. Pharmacol. 32, 413-422.

Chen, T., H. L. He and G. M. Church (1999b). Modeling gene expression with differential equations. Pac. Symp. Biocomput. 29-40.

Chew, C. S. (1983). Inhibitory action of somatostatin on isolated gastric glands and parietal cells. Am. J. Physiol. 245, G221-G229. 
Chew, C. S. and S. J. Hersey (1982). Gastrin stimulation of isolated gastric glands. Am. J. Physiol. 242, G504-G512.

Culshaw, R. V. and S. Ruan (2000). A delay-differential equation model of HIV infection of CD4(+) T-cells. Math. Biosci. 165, 27-39.

D’Adda, T., A. Bertele, F. P. Pilato and C. Bordi (1989). Quantitative electron microscopy of endocrine cells in oxyntic mucosa of normal human stomach. Cell Tissue Res. $\mathbf{2 5 5}$, 41.

de Beus, A. M., T. L. Fabry and H. M. Lacker (1993). A gastric acid secretion model. Biophys. J. 65, 362-378.

Debas, H. T. and S. H. Carvajal (1994). Vagal regulation of acid secretion and gastrin release. Yale J. Biol. Med. 67, 145-151.

De Gaetano, A. and O. Arino (2000). Mathematical modelling of the intravenous glucose tolerance test. J. Math. Biol. 40, 136-168.

Dockray, G. J. (1999). Topical review. Gastrin and gastric epithelial physiology. J. Physiol. (Lond) 518, 315-324.

Engel, E. Jr., A. Peskoff, G. L. Kauffman and M. I. Grossman (1984). Analysis of hydrogen ion concentration in the gastric gel mucus layer. Am. J. Physiol. 247, G321-G338.

Hakanson, R., D. Chen, E. Lindstrom, P. Norlen, M. Bjorkqvist and D. Lehto-Axtelius (1998). Physiology of the ECL cells. Yale J. Biol. Med. 71, 163-171.

Hansen, C. P., F. Stadil, L. Yucun and J. F. Rehfeld (1996). Pharmacokinetics and organ metabolism of carboxyamidated and glycine-extended gastrins in pigs. Am. J. Physiol. 271, G156.

Hattori, T. and N. Arizono (1988). Cell kinetics and secretion of mucus in the gastrointestinal mucosa, and their diurnal rhythm. J. Clin. Gastroenterol. 10, S1-S6.

Helander, H. F., K. Rutgersson, K. G. Helander, J. P. Pisegna, J. D. Gardner, R. T. Jensen and P. N. Maton (1992). Stereologic investigations of human gastric mucosa. II. Oxyntic mucosa from patients with Zollinger-Ellison syndrome. Scand. J. Gastroenterol. 27, 875.

Hersey, S. J. and G. Sachs (1995). Gastric acid secretion. Physiol. Rev. 75, 155-189.

Hildebrand, P., J. W. Ensinck, J. Buettiker, J. Drewe, B. Burckhardt, K. Gyr and C. Beglinger (1994). Circulating somatostatin-28 is not a physiologic regulator of gastric acid production in man. Eur. J. Clin. Invest. 24, 50.

Holst, J. J., S. Knuhtsen, C. Orskov, T. Skak-Nielsen, S. S. Poulsen and O. V. Nielsen (1987). GRP-producing nerves control antral somatostatin and gastrin secretion in pigs. Am. J. Physiol. 253, G767.

Inokuchi, H., S. Fujimoto and K. Kawai (1983). Cellular kinetics of gastrointestinal mucosa, with special reference to gut endocrine cells. Arch. Histol. Jpn. 46, 137-157.

Joseph, I. M., Y. Zavros, J. Merchant and D. Kirschner (2002). A model for integrative study of human gastric acid secretion. J. Appl. Physiol. 8, 8.

Karam, S. M. (1993). Dynamics of epithelial cells in the corpus of the mouse stomach. IV. Bidirectional migration of parietal cells ending in their gradual degeneration and loss. Anat. Rec. 236, 314-332.

Karam, S. M. (1995). New insights into the stem cells and the precursors of the gastric epithelium. Nutrition 11, 607-613.

Karam, S. M. (1999). Lineage commitment and maturation of epithelial cells in the gut. Front. Biosci. 4, D286-D298.

Karam, S. M. and C. P. Leblond (1993a). Dynamics of epithelial cells in the corpus of the mouse stomach. I. Identification of proliferative cell types and pinpointing of the stem cell. Anat. Rec. 236, 259-279. 
Karam, S. M. and C. P. Leblond (1993b). Dynamics of epithelial cells in the corpus of the mouse stomach. II. Outward migration of pit cells. Anat. Rec. 236, 280-296.

Karam, S. M. and C. P. Leblond (1993c). Dynamics of epithelial cells in the corpus of the mouse stomach. III. Inward migration of neck cells followed by progressive transformation into zymogenic cells. Anat. Rec. 236, 297-313.

Karam, S. M. and C. P. Leblond (1993d). Dynamics of epithelial cells in the corpus of the mouse stomach. V. Behavior of entero-endocrine and caveolated cells: general conclusions on cell kinetics in the oxyntic epithelium. Anat. Rec. 236, 333-340.

Karam, S. and C. P. Leblond (1995). Origin and migratory pathways of the eleven epithelial cell types present in the body of the mouse stomach. Microsc. Res. Tech. 31, 193-214.

Karam, S. M., Q. Li and J. I. Gordon (1997). Gastric epithelial morphogenesis in normal and transgenic mice. Am. J. Physiol. 272, G1209-G1220.

Keener, J. P. and J. Sneyd (1998). Mathematical Physiology, New York: Springer.

Koh, T. J. and D. Chen (2000). Gastrin as a growth factor in the gastrointestinal tract [In Process Citation]. Regul. Pept. 93, 37-44.

Konturek, S. J. (1982). Cholinergic control of gastric acid secretion in man. Scand. J. Gastroenterol. Suppl. 72, 1-5.

Koop, H., I. Behrens, E. Bothe, C. H. McIntosh, R. A. Pederson, R. Arnold and W. Creutzfeldt (1982). Adrenergic and cholinergic interactions in rat gastric somatostatin and gastrin release. Digestion 25, 96-102.

Kuang, Y. (1993). Delay Differential Equations: With Applications in Population Dynamics, Cambridge, MA: Academic Press.

Lambert, J. D. (1991). Numerical Methods for Ordinary Differential Systems: The Initial Value Problem, Chichester, New York: Wiley.

Licko, V. and E. B. Ekblad (1992a). Dynamics of a metabolic system: what single-action agents reveal about acid secretion. Am. J. Physiol. 262, G581-G592.

Licko, V. and E. B. Ekblad (1992b). What dual-action agents reveal about acid secretion: a combined experimental and modeling analysis. Biochim. Biophys. Acta 1137, 19-28.

Lindstrom, E., D. Chen, P. Norlen, K. Andersson and R. Hakanson (2001). Control of gastric acid secretion:the gastrin-ECL cell-parietal cell axis. Comp. Biochem. Physiol. A Mol. Integr. Physiol. 128, 505-514.

Lindstrom, E. and R. Hakanson (2001). Neurohormonal regulation of secretion from isolated rat stomach ECL cells: a critical reappraisal. Regul. Pept. 97, 169-180.

Lundell, L., G. Lindstedt and L. Olbe (1987). Origin of gastrin liberated by gastrin releasing peptide in man. Gut 28, 1128-1133.

Makhlouf, G. M. and M. L. Schubert (1990). Gastric somatostatin: a paracrine regulator of acid secretion. Metabolism 39, 138.

Matsuno, M., T. Matsui, A. Iwasaki and Y. Arakawa (1997). Role of acetylcholine and gastrin-releasing peptide (GRP) in gastrin secretion. J. Gastroenterol. 32, 579-586.

Murray, J. D. (2001). Mathematical Biology, New York: Springer.

Naik, S. R., S. C. Bajaj, R. K. Goyal, D. N. Gupta and H. K. Chuttani (1971). Parietal cell mass in healthy human stomach. Gastroenterology 61, 682.

Nishi, S., Y. Seino, J. Takemura, H. Ishida, M. Seno, T. Chiba, C. Yanaihara, N. Yanaihara and H. Imura (1985). Vagal regulation of GRP, gastric somatostatin, and gastrin secretion in vitro. Am. J. Physiol. 248, E425-E431.

Nomiyama, S., B. Nishioka, T. Ishii, K. Nakamura and S. Majima (1981). Comparative study of G- and D-cell population in the dog stomach. Jpn. J. Surg. 11, 346. 
Pansu, D., A. Berard and R. Lambert (1977). Regulation of cell renewal in the gastrointestinal mucosa (author's transl). Pathol. Biol. (Paris) 25, 119-133.

Rocheville, M., D. C. Lange, U. Kumar, R. Sasi, R. C. Patel and Y. C. Patel (2000). Subtypes of the somatostatin receptor assemble as functional homo- and hetero-dimers. J. Biol. Chem. 275, 7862.

Royston, C. M., J. Polak, S. R. Bloom, W. M. Cooke, R. C. Russell, A. G. Pearse, J. Spencer, R. B. Welbourn and J. H. Baron (1978). G cell population of the gastric antrum, plasma gastrin, and gastric acid secretion in patients with and without duodenal ulcer. Gut 19, 689.

Saffouri, B., G. C. Weir, K. N. Bitar and G. M. Makhlouf (1980). Gastrin and somatostatin secretion by perfused rat stomach: functional linkage of antral peptides. Am. J. Physiol. 238, G495-G501.

Sato, F., S. Muramatsu, S. Tsuchihashi, A. Shiragai, T. Hiraoka, T. Inada, K. Kawashima, H. Matsuzawa, W. Nakamura, E. Trucco and G. A. Sacher (1972). Radiation effects on cell populations in the intestinal epithelium of mice and its theory. Cell Tissue Kinet. 5, 227-235.

Schaffer, K., H. Herrmuth, J. Mueller, D. H. Coy, H. C. Wong, J. H. Walsh, M. Classen, V. Schusdziarra and W. Schepp (1997). Bombesin-like peptides stimulate somatostatin release from rat fundic D cells in primary culture. Am. J. Physiol. 273, G686.

Schubert, M. L., N. F. Edwards, A. Arimura and G. M. Makhlouf (1987). Paracrine regulation of gastric acid secretion by fundic somatostatin. Am. J. Physiol. 252, G485.

Schwarting, H., H. Koop, G. Gellert and R. Arnold (1986). Effect of starvation on endocrine cells in the rat stomach. Regul. Pept. 14, 33-39.

Simonsson, M., S. Eriksson, R. Hakanson, T. Lind, H. Lonroth, L. Lundell, D. T. O'Connor and F. Sundler (1988). Endocrine cells in the human oxyntic mucosa. A histochemical study. Scand. J. Gastroenterol. 23, 1089.

Solcia, E., C. Capella, F. Sessa, G. Rindi, M. Cornaggia, C. Riva and L. Villani (1986). Gastric carcinoids and related endocrine growths. Digestion 35, 3 .

Takahashi, T., H. Shimazu, T. Yamagishi and M. Tani (1979). G-cell population in antral mucosa of the dog. Dig. Dis. Sci. $\mathbf{2 4}, 921$.

Tam, J. (1999). Delay effect in a model for virus replication. IMA J. Math. Appl. Med. Biol. 16, 29-37.

Weigert, N., Y. Y. Li, R. R. Schick, D. H. Coy, M. Classen and V. Schusdziarra (1997). Role of vagal fibers and bombesin/gastrin-releasing peptide-neurons in distention-induced gastrin release in rats. Regul. Pept. 69, 33-40.

Wollin, A. (1987). Regulation of gastric acid secretion at the cellular level. Clin. Invest. Med. 10, 209-214. 